\title{
New Directions in Exercise Prescription: Is There a Role for Brain-Derived Parameters Obtained by Functional Near-Infrared Spectroscopy?
}

\author{
Fabian Herold ${ }^{1,2, *(\mathbb{D})}$, Thomas Gronwald ${ }^{3} \mathbb{C}^{\circ}$, Felix Scholkmann ${ }^{4,5}$, Hamoon Zohdi ${ }^{5}{ }^{(}$, \\ Dominik Wyser $^{4,6}$, Notger G. Müller ${ }^{1,2,7}$ and Dennis Hamacher ${ }^{8}$ (D) \\ 1 Department of Neurology, Medical Faculty, Otto von Guericke University, Leipziger Str. 44, \\ 39120 Magdeburg, Germany; notger.mueller@dzne.de \\ 2 Research Group Neuroprotection, German Center for Neurodegenerative Diseases (DZNE), Leipziger Str. 44, \\ 39120 Magdeburg, Germany \\ 3 Department Performance, Neuroscience, Therapy and Health, MSH Medical School Hamburg, \\ University of Applied Sciences and Medical University, Am Kaiserkai 1, 20457 Hamburg, Germany; \\ Thomas.Gronwald@medicalschool-hamburg.de \\ 4 Department of Neonatology, Biomedical Optics Research Laboratory, University Hospital Zurich, \\ University of Zurich, 8091 Zurich, Switzerland; felix.scholkmann@usz.ch (F.S.); \\ dominik.wyser@hest.ethz.ch (D.W.) \\ 5 Institute for Complementary and Integrative Medicine, University of Bern, 3012 Bern, Switzerland; \\ hamoon.zohdi@ikim.unibe.ch \\ 6 ETH Zurich, Rehabilitation Engineering Laboratory, Department of Health Sciences and Technology, \\ 8092 Zurich, Switzerland \\ 7 Center for Behavioral Brain Sciences (CBBS), Universitätsplatz 2, 39106 Magdeburg, Germany \\ 8 German University for Health and Sports, (DHGS), Vulkanstraße 1, 10367 Berlin, Germany; \\ Dennis.Hamacher@dhgs-hochschule.de \\ * Correspondence: fabian.herold@st.ovgu.de
}

Received: 29 April 2020; Accepted: 29 May 2020; Published: 3 June 2020

\begin{abstract}
In the literature, it is well established that regular physical exercise is a powerful strategy to promote brain health and to improve cognitive performance. However, exact knowledge about which exercise prescription would be optimal in the setting of exercise-cognition science is lacking. While there is a strong theoretical rationale for using indicators of internal load (e.g., heart rate) in exercise prescription, the most suitable parameters have yet to be determined. In this perspective article, we discuss the role of brain-derived parameters (e.g., brain activity) as valuable indicators of internal load which can be beneficial for individualizing the exercise prescription in exercise-cognition research. Therefore, we focus on the application of functional near-infrared spectroscopy (fNIRS), since this neuroimaging modality provides specific advantages, making it well suited for monitoring cortical hemodynamics as a proxy of brain activity during physical exercise.
\end{abstract}

Keywords: cognition; personalized training; personalized medicine; exercise prescription

\section{Introduction}

There is a robust body of literature suggesting that regularly conducted physical activity (typically engendered through regular physical exercise) promotes brain health and cognitive performance regardless of age [1-11]. However, the multilevel mechanisms driving exercise-induced neurocognitive changes across different age groups are not well understood $[7,12,13]$ and little is known about which exercise prescription (e.g., intensity, duration, type of exercise) might be optimal to promote neurocognitive changes $[1,7,8,14-23]$. An adequate exercise prescription is the key to appropriately 
individualize physical exercise $[15,24,25]$, but there is an ongoing debate about the optimal selection of parameters to do so [26-36]. This debate has now reached the field of exercise-cognition science [37-39] and could be a promising starting point to optimize exercise prescription.

To prescribe physical exercise, both parameters of external load (e.g., workload in Watts) and indicators of internal load (e.g., changes in heart rate) can be used. In this regard, external load is defined as work that an individual performs regardless of internal characteristics, whereas internal load encompasses the individual and acute psychophysiological responses to the external load, as well as influencing factors (environmental factors and lifestyle factors that amplify or diminish the physical exercise stimuli) $[15,25,40-47]$. In addition, it is important to emphasize that the external load has to be carefully adjusted to achieve a specific internal load. More importantly, specific indicators of internal load can be used as a proxy of the dose [15,25], which influences the effectiveness of an intervention $[15,48,49]$. However, it is currently not clear which indicator of internal load is the most suitable one to prescribe, for instance, exercise intensity in exercise-cognition science [15]. To extend this debate, we will discuss in this perspective article the role of brain-derived parameters as indicators of internal load and how these parameters serve to prescribe, rather than to solely monitor physical exercises (i.e., exercise intensity). Therefore, (i) we review which portable neuroimaging method would currently be the most suitable to monitor brain activity during physical exercise, (ii) we describe the neurophysiological background of this neuroimaging method and selected application-relevant methodological details, (iii) we explain the advantages of brain-derived parameters compared to conventional indicators of internal load (e.g., heart rate), and (iv) we outline potential opportunities for further investigation.

\section{Which Portable Neuroimaging Tools Can Be Used to Assess Brain Activation During Physical Exercises?}

Currently, there exist two portable neuroimaging modalities, namely electroencephalography (EEG) and functional near-infrared spectroscopy (fNIRS), to investigate brain activity during physical exercises in relatively unconstrained environments [50-52]. An overview on commercially available systems can be found in the review of Peake et al. [53]. Using EEG, brain activity is directly assessed by measuring electric changes in cortical layers [54]. Using fNIRS, brain activity is indirectly assessed by measuring cortical hemodynamic changes as a proxy of brain activity $[50,55]$. EEG has been applied in a variety of physical tasks and/or physical exercises (for review see [56]), such as balancing [57-63], walking [64-69], resistance exercises [70-72], or cycling [73-79]. Compared to fNIRS, EEG provides the advantage of a high temporal resolution (e.g., $>1000 \mathrm{~Hz}$ ) [80-85]. On the downside, EEG has the drawbacks of (i) a low spatial resolution (i.e., $\sim 5$ to $9 \mathrm{~cm}$; with Laplacian transformation $\sim 3 \mathrm{~cm}$ ) [80-87], (ii) a time-consuming preparation when gel is used with wet electrodes [84,86], (iii) a high susceptibility to artefacts arising from motion, muscles, or sweat [80,81,87-90], and (iv) a hard interpretability of obtained signals for non-experts [91]. In contrast, fNIRS provides the advantages of a relatively high spatial resolution (i.e., $\sim 1-3 \mathrm{~cm}$ ) and a relatively high tolerance against motion artefacts $[81,83,84,86,92-98]$, but suffers from a susceptibility to systemic physiological artefacts (e.g., superficial blood flow) [83,94,95,99-101]. Based on the drawbacks of EEG and the advantages of fNIRS, fNIRS is currently better suited for measurements of changes in cortical brain activity during physical exercises in unconstrained environments [50,102,103]. In fact, fNIRS has been applied during a variety of physical exercises such as juggling [104], balancing [105-110], walking (for review see [111,112]), resistance exercises [113-116], dancing [117-119], tai chi [120,121], climbing [122], synchronized swimming routines [123], table tennis [124], running [125-127], and predominantly during cycling [128-165]. Furthermore, fNIRS was used to monitor cerebral oxygenation during stationary cycling even in special cohorts, such as cardiac patients [166-169]. However, in the mentioned studies, fNIRS was only utilized to monitor brain activity during exercising, while, to our knowledge, no study so far has used fNIRS-based parameters to prescribe exercise variables (e.g., exercise intensity). 


\section{Neurophysiological Mechanisms and Physical Principles of fNIRS}

The optical neuroimaging technique fNIRS allows the non-invasive imaging of cerebral hemodynamics from cortical layers in the human brain $[83,111]$. Neuroimaging based on fNIRS utilizes the physical principles of optical spectroscopy and the physiological processes of neurometabolic and neurovascular coupling [83], which are illustrated in Figure 1a. The execution of a distinct task (e.g., a motor-cognitive exercise such as dancing) causes a higher neural activation in specific brain regions. In order to supply the energy needed to satisfy the energetic demands of the activated neuronal tissue, the oxygen metabolism (neurometabolic coupling) is increased [83,170,171], leading to a higher metabolization rate of oxygen [170-172]. In consequence of the higher rate of oxygen metabolization, the local concentration of oxygenated hemoglobin $(\mathrm{oxyHb})$ decreases and the local concentration of deoxygenated hemoglobin (deoxyHb) increases [170-173]. Furthermore, as shown in Figure 1a, an increase in neural activity also triggers local changes in cerebral hemodynamics and induces an intensified blood flow to the activated brain regions $[83,170,174-176]$. As a sequel of the locally increased blood flow, the local supply of oxygen is greater than its metabolization and, thus, a higher concentration of oxyHb and a decreased concentration in deoxyHb is to be observed in activated brain regions (see Figure 1a) $[83,171,176]$. These neural activity-dependent changes in oxy $\mathrm{Hb}$ and deoxy $\mathrm{Hb}$ concentrations can be used as indirect indicators of brain activation. To assess the neural activity-dependent changes in oxyHb and deoxyHb with fNIRS, light with distinct wavelengths in the near-infrared spectrum is emitted by a source (e.g., laser or light emitting diodes (LED)) on the scalp into the skull (see Figure 1b) $[83,177,178]$. Inside the skull, the emitted light travels through different layers (e.g., cerebrospinal fluid) and ideally penetrates the neural tissue $[83,177,178]$. In all the tissues of the head (intracerebral and extracerebral), the emitted near-infrared light undergoes scattering events and absorption processes, leading to light attenuation at the detectors [92,178,179]. Scattering events increase the length of their traveled photon paths as it forces the photons to deviate from their initial straight trajectories [83,92]. Absorption processes lead to a transformation of the initial energy of the photons into the internal energy of the respective medium (e.g., neural tissue) [83]. Based on the different absorption spectra of the chromophores (e.g., $\lambda>800 \mathrm{~nm}$ mainly oxyHb, $\lambda<800 \mathrm{~nm}$ mainly deoxy $\mathrm{Hb}$ ), neural activity-dependent changes in the local concentration of oxy $\mathrm{Hb}$ and deoxyHb influence the local light absorption rate and, in turn, the regional magnitude of light attenuation $[83,93,178]$. These neural activity-dependent changes in light attenuation can be assessed by measuring the non-absorbed components of the emitted light using a detector that is placed on the head's surface (see Figure 1b) $[177,178]$. Changes in light attenuation can be linked to local changes in cortical oxyHb and deoxyHb concentrations by means of the modified Beer-Lambert law, enabling a non-invasive quantification of the "indirect" indicators of brain activity changes $[83,177,178]$. 


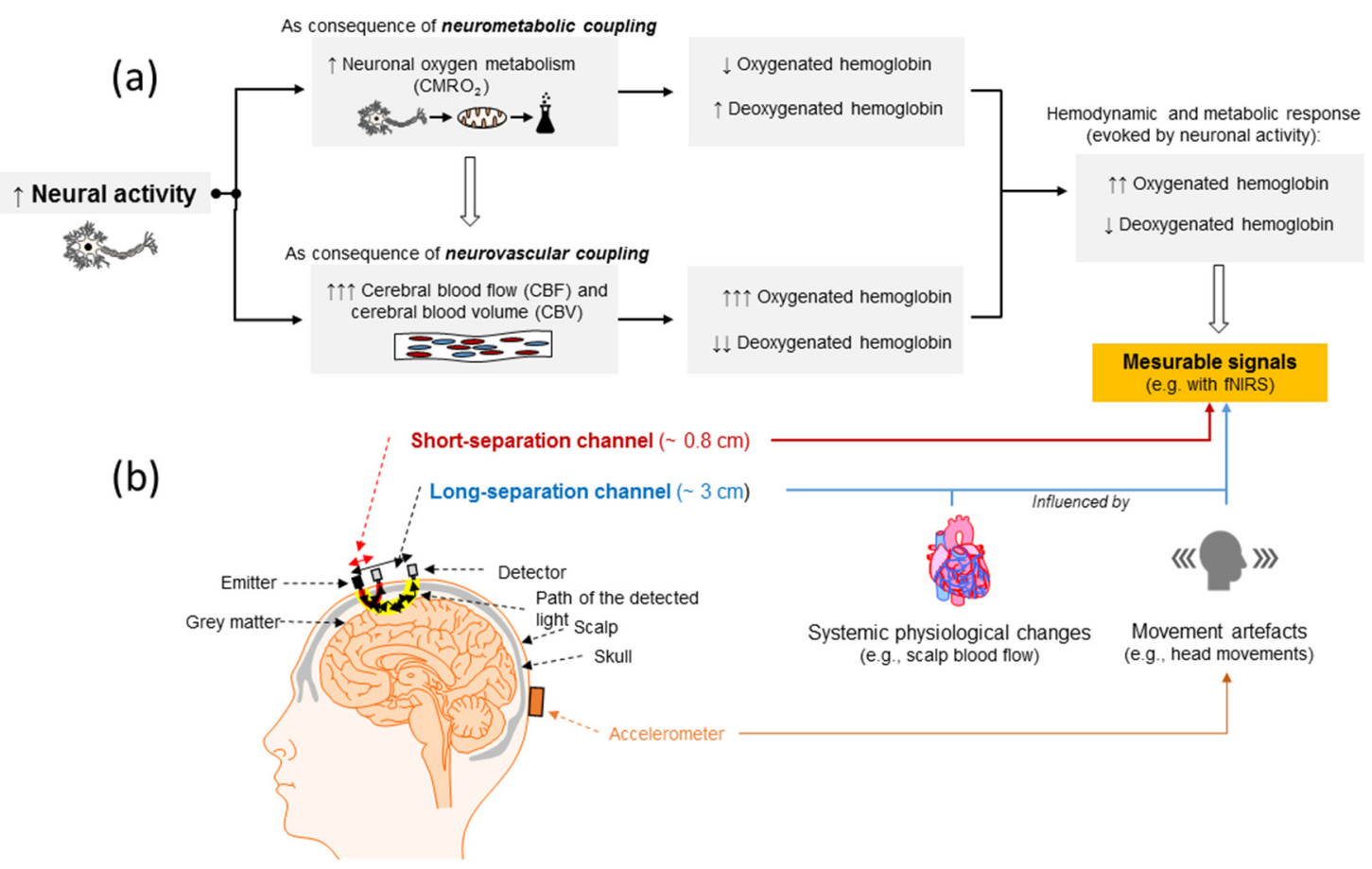

Figure 1. Schematic illustrations of (a) changes in cerebral hemodynamics and oxygen, induced by neural activity. (b) Depiction of a possible NIRS montage on the human head showing the assumed banana-shaped course of detected light of "short separation channels" and of "long separation channels"; fNIRS, functional near-infrared spectroscopy; $\mathrm{CMRO}_{2}$, cerebral metabolic rate of oxygen; $\uparrow$, increase; $\downarrow$, decrease.

With regard to the technical implementation of (functional) near-infrared spectroscopy ((f)NIRS), it is important to emphasize that the following four different methods exist. These different methods have unique advantages and disadvantages with respect to the usage in the field of exercise(-cognition) science: (i) continuous-wave NIRS (CW-NIRS), (ii) spatially resolved NIRS (SRS-NIRS), (iii) frequency domain NIRS (FD-NIRS) and (iv) time domain NIRS (TD-NIRS).

(i) In CW-NIRS devices, the changes in light intensity (i.e., attenuation) are used to calculate the relative concentration changes in chromophores (e.g., oxyHb and deoxyHb) [98,171,174,180,181]. Light with a distinct intensity is emitted into the tissue (e.g., brain and scalp tissue) via an emitter (e.g., placed on the scalp) and the non-absorbed light components leaving the tissue at a distinct point are measured via a detector, from which the intensity of outgoing light is obtained. By using CW-NIRS, changes in the attenuation coefficient can be calculated and used to determine the relative concentration changes in the chromophores (e.g., relative to baseline) [171,182].

(ii) SRS-NIRS is a special type of CW-NIRS. In SRS-NIRS, at least two detectors (e.g., placed on the head surface) are used to measure the light which leaves the examined tissue after traveling through it (e.g., brain and scalp tissue) [183]. The information of the two detectors is used to determine the local gradients of light attenuation which, in turn, can be used to calculate the absolute concentration changes in chromophores (e.g., oxyHb and deoxyHb) and the tissue oxygenation index (TOI) [184,185]. TOI is the ratio of oxyHb to total hemoglobin (sum of oxyand deoxy $\mathrm{Hb}$ ) and is also known as the tissue saturation index (TSI) and regional tissue oxygen saturation $\left(\mathrm{StO}_{2}\right.$, and $\left.\mathrm{rSO}_{2}\right)$.

(iii) In FD-NIRS, the source(s) (e.g., placed on the scalp) continuously emit(s) light with a distinct intensity into the tissue, whose amplitude is modulated at a specific frequency in the $\mathrm{MHz}$ range. A detector (e.g., placed on the head's surface) measures the phase shift (delay) and light attenuation of the measured and non-absorbed light components, which, in turn, are used to determine the absorption and scattering properties of the specific tissue (e.g., brain tissue). 
Using the individual-specific information about the scattering and absorption properties of the distinct tissue allows the quantification of absolute concentration changes in the chromophores (e.g., oxyHb and deoxyHb) [98,171,174,180,181,186,187].

(iv) In TD-NIRS, multiple sources emit extremely short light impulses into the tissue (e.g., brain and scalp tissue) and detectors, placed at a certain distance from the light emitting source, quantify the time of flight, the temporal distribution, and the shape of the temporal distribution of the non-absorbed photons, which leave the examined tissue (e.g., brain and scalp tissue). The information about the time of flight, temporal distribution, and shape of the temporal distribution of the non-absorbed photons are used to determine the scattering and absorption properties of the distinct tissue (e.g., brain tissue). In general, photons that travelled through the cerebral tissue are more delayed than photons that are only traveling through the scalp. The obtained information about scattering and absorption enables the calculation of absolute concentrations changes in chromophores (e.g., oxyHb and deoxyHb) $[98,171,174,180,181,186,187]$.

With regard to the application of fNIRS in the field of exercise science (in particular to prescribe exercise), SRS-NIRS is the most promising of the four NIRS methods. SRS-NIRS allows, compared to CW-NIRS, the quantification of absolute changes in the concentration of chromophores [184,185], and, compared to FD-NIRS and TD-NIRS, SRS-NIRS devices are less expensive, have a higher acquisition rate, and are less bulky $[98,180,188]$. Furthermore, TD-NIRS suffers from the drawback that it is not able to detect small functional activation changes due to its working principle, which is based on time of flight photon detection. The latter returns a noisier parameter compared to SRS-NIRS, which is based on light attenuation measurement $[171,180,188]$. Moreover, multi-distance configurations of NIRS channels, as used in SRS-NIRS, allow measurements that are more robust against motion artefacts, resulting in a more stable acquisition of the signals [184]. In addition, in the field of exercise science, NIRS systems with LED sources (e.g., SRS-NIRS) are more suitable because they allow smaller and portable instrumentation and are safer in their application, as compared to NIRS systems with laser sources (e.g., FD-NIRS and TD-NIRS) [171,189]. More detailed information about the differences between CW-NIRS, SRS-NIRS, FD-NIRS, and TD-NIRS can be found in the referenced literature $[98,171,174,180,181,183,185,186,190-196]$.

\section{Advantages of Brain-Derived Indicators of Internal Load}

In this section, we discuss the advantages of brain-derived indicators of internal load to prescribe physical exercise in exercise-cognition research. Therefore, we focus on the exercise variable exercise intensity because a full discussion of all exercise variables is beyond the scope of this perspective article. It is undoubted that the established approach prescribing the exercise intensity using specific indicators of internal load, such as percentages of maximal heart rate $\left(\mathrm{HR}_{\max }\right)$ or maximal oxygen uptake $\left(\mathrm{VO}_{2}\right.$ max $)$, which were obtained during a preceding graded exercise test, has its merits. However, this established approach for the prescription of exercise intensity can cause a considerable amount of interindividual heterogeneity in neurocognitive outcomes [15]. Hence, we recommend alternative approaches to exercise prescription, which make use of specific indicators of internal load, and which are known to be causally related to the intended outcome [15]. In this respect, fNIRS-derived brain parameters (e.g., oxy $\mathrm{Hb}$, deoxy $\mathrm{Hb}$, totHb, or $\mathrm{StO}_{2}$ ) can be a promising option for prescribing exercise intensity because they are more closely related to the organic system which is intended to be modulated (i.e., brain). This assumption is supported by the evidence outlined in the following:

(a) cortical hemodynamics are sensitive to the level of physical load (e.g., exercise intensity) $[125,126,128,139]$ and a decline in prefrontal oxygenation (i.e., oxyHb and $\mathrm{StO}_{2} / \mathrm{TOI}$ ) at very high exercise intensities was observed $[126,158,164,197,198]$. The latter corroborates the notion of a "central governor" limiting maximal exercise performance [198-205],

(b) cortical hemodynamics are sensitive to the influence of psychophysiological parameters (e.g., exercise tolerance) $[129,206]$, 
(c) cortical hemodynamics during physical exercise are indicators of responsiveness, as levels of oxyHb in the right ventrolateral prefrontal cortex (PFC) during exercise are higher in individuals who show superior performance in a spatial memory task (e.g., being responders) after an acute bout of physical exercise [207],

(d) the level of cortical hemodynamics during physical exercise might act as an indicator of the optimal brain state since lower levels of oxygenated hemoglobin in the PFC during physical exercise were associated with slower reaction times in an executive function task (i.e., Stroop task [208].

Regarding (c) and (d), comparable findings have, to the best of our knowledge, not been reported for conventional parameters of exercise prescription (e.g., heart rate (HR)) when neurocognitive outcomes were considered. Hence, (c) and (d) of the above-mentioned points especially support the idea that brain-derived parameters may be superior when prescribing physical exercise (e.g., exercise intensity) in the setting of exercise-cognition research. Moreover, commonly used conventional parameters of exercise prescription, such as HR, also suffer from the drawback that they are not able to sufficiently reflect psychophysiological responses to non-cardiorespiratory demands (e.g., cognitive load), which are posed by non-endurance exercises, such as simultaneous motor-cognitive exercise (e.g., dancing [14]). However, these demands are mirrored in brain-derived measures. Regarding fNIRS-derived brain parameters, it was reported that they are sensitive to:

(e) the level of cognitive load [209-212],

(f) the level of cognitive fatigue [213-215],

(g) the influence of stress [216-220],

(h) the influence of expertise level [104,122,212,221] or skill level [106,222],

(i) training-related changes in motor-cognitive performance $[105,117]$.

Accordingly, the provided evidence further buttresses the idea to use brain-derived parameters in exercise prescription. Brain-derived parameters, as compared to conventional parameters, have, at least theoretically, an added value in exercise prescription. Both the monitoring of brain parameters (e.g., during the course of a physical intervention) and the use of brain parameters to prescribe physical exercises (i.e., exercise intensity) are valuable options to gain more knowledge about the exercise-cognition interaction. The first approach (i.e., solely monitoring cerebral hemodynamics) can help us to answer specific research questions related to the effects of exercise on the brain which, in turn, can later be used to inform exercise prescription (e.g., To what extent does an exercise prescription based on conventional parameters cause interindividual heterogeneity concerning cerebral hemodynamics?). The second approach (i.e., brain-derived parameters to prescribe exercise) opens a new perspective, as it allows the study of the effects of an alternative exercise prescription on specific outcome measures (e.g., To what extent does an exercise prescription based on brain-derived parameters influence interindividual heterogeneity in cognitive performance changes in response to an acute bout of physical exercise?). Hence, both approaches should be seen as complementary options, which enable us to study the subject of exercise-cognition from two different perspectives.

\section{Practical Implementation of Brain-Derived Parameters to Prescribe Physical Exercise}

In the previous section, we have outlined that there is a strong theoretical rationale to use brain-derived parameters to prescribe exercise variables (e.g., exercise intensity), but this approach is currently underutilized. As this approach will open a new perspective on exercise-cognition interaction, we highlight potential areas of application by answering the following questions, which seem relevant for the practical implementation: (i) How Can We Prescribe Exercise Intensity by Using fNIRS-Derived Brain Parameters?, (ii) Which Cortical Brain Area Should Be Targeted?, (iii) How Can We Minimize Confounders in Order to Successfully Apply fNIRS During Physical Exercise? and (iv) Which Additional Internal Load Indicators Should Be Recorded Alongside fNIRS? 


\subsection{How Can We Prescribe Exercise Intensity by Using fNIRS-Derived Brain Parameters?}

In our opinion, a prescription of exercise intensity using fNIRS-derived brain parameters can be implemented in a manner comparable to routinely used conventional indicators of internal load (HR). To test the practicability of the novel approach to prescribe exercise intensity by using fNIRS-derived brain parameters, continuous endurance exercises (e.g., cycling) could be a good starting point. Similar to the conventional approach of exercise prescription, the individual firstly performs a graded exercise test in which brain-derived indicators of internal load (e.g., $\mathrm{StO}_{2}$ ) can be measured alongside conventional ones (e.g., $\mathrm{HR}$ or $\mathrm{VO}_{2}$ ). Based on this graded exercise test, the external load (e.g., workload) can be identified, which corresponds, for instance, to the highest $\mathrm{StO}_{2}$ or to a specific percentage of a maximal $\mathrm{StO}_{2}$ (see Figure 2). This external load (i.e., workload) can then, in turn, be used to set the initial exercise intensity in an exercise session. Importantly, as fNIRS allows a non-invasive online monitoring of brain parameters, such as $\mathrm{StO}_{2}$ while exercising, the external load can be individually adjusted during the course of the exercise session, in order to ensure that the target $\mathrm{StO}_{2}$ is achieved (e.g., comparable to $\mathrm{HR}$ monitoring). Hence, using brain parameters, such as $\mathrm{StO}_{2}$, allows one to account for daily variations in performance capacity in the same manner as the established conventional approaches (e.g., heart rate monitoring). However, before the application of fNIRS can be recommended unreservedly, further research is necessary. Such research should aim, for instance, at investigating the reproducibility of fNIRS-derived brain parameters in the exercise setting, at studying the relationship between fNIRS-derived brain parameters and conventional parameters of exercise prescription (e.g., HR, level of peripheral blood lactate, and relative perceived exertion (RPE)), and at examining whether this novel approach of exercise prescription may be superior in inducing neurocognitive changes (e.g., acute influence on cognitive performance or blood-based markers), as compared to conventional approaches of exercise prescription.

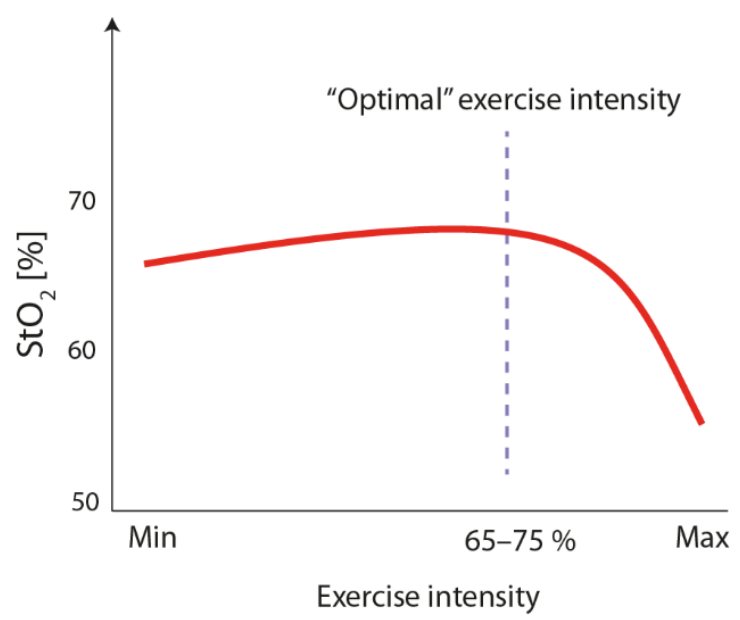

Figure 2. Schematic illustration of the time course of $\mathrm{StO}_{2}$ during a graded exercise test to exhaustion. The optimum is tentatively defined as the lowest exercise intensity leading to the highest cerebral oxygenation (marked by the dashed line).

\subsection{Which Cortical Brain Area Should Be Targeted?}

The exact placement of fNIRS optodes is crucial to obtaining cerebral hemodynamic signals from a specific brain area. To test the practicability of an exercise prescription which is based on brain-derived measures, we propose that the PFC could be a promising initial target area. The PFC is a key structure for the performance of cognitive control/executive functions [223,224], which is the most investigated cognitive domain in acute exercise-cognition studies [225]. More specifically, and based on evidence that is outlined in more detail below, the ventrolateral PFC, dorsolateral PFC, and the frontopolar area (FPA) are promising brain areas for investigations: 
(a) Regarding the ventrolateral PFC; it was observed that young adults with superior performance in a spatial memory tasks in response to an acute bout of endurance exercise (i.e., responders) exhibited higher levels of oxyHb in the right ventrolateral PFC during the exercise [207].

(b) Regarding the dorsolateral PFC; it was noticed that in young adults, higher levels of oxyHb in the left dorsolateral PFC (measured during a cognitive test after exercising) [226-228] were associated with exercise-induced behavioral changes in the performance of the Stroop test.

(c) Regarding the FPA; it was observed that in young adults, higher levels of oxyHb in the left FPA (measured during a cognitive test after exercising) [227] were associated with exercise-induced behavioral changes in the performance of the Stroop test. Similar findings have been observed for older adults regarding the right FPA [229].

In addition, more detailed information regarding an accurate and standardized placement of fNIRS optodes can be found in the referenced literature [176].

\subsection{How Can We Minimize Confounders in Order to Successfully Apply fNIRS during Physical Exercise?}

With respect to the practical application of fNIRS during physical exercising, it is mandatory to emphasize that movement artefacts or systemic physiological artefacts, which occur during physical exercising, influence the accuracy of the brain signal measurement of fNIRS significantly [99,101,149,151, 230-235]. To minimize the influence of such signal confounders, appropriate data processing techniques should be applied (e.g., short-separation channel regression (SSR) to account for superficial blood flow $[99,111,176,235,236]$ or SSR in conjunction with accelerometer signals to account for superficial blood flow and motion artefacts in CW-NIRS [237]). Furthermore, the application of other NIRS methods, namely SRS-NIRS, should be considered in the context of physical exercise, since they are less influenced by systemic physiological interference [238] and motion-related artefacts [184].

In addition, it is strongly recommended to record multiple physiological signals along with fNIRS signals (e.g., HR and heart rate variability (HRV), electrodermal activity (skin conductance), mean arterial blood pressure, systolic and diastolic blood pressure, respiration rate, and partial pressure of exhaled $\mathrm{CO}_{2}\left(\mathrm{P}_{\mathrm{ET}} \mathrm{CO}_{2}\right)$ ) to make valid assumptions about the physiological origin of the observed changes in fNIRS signals and, in turn, to improve the interpretation of fNIRS signals [99]. This approach has been recently termed systematic physiological augmented functional near-infrared spectroscopy (SPA-fNIRS) [239,240]. However, the study of Tempest et al. [108] supports the application of fNIRS, for instance, during motor-cognitive exercises, as robust cognitive task-evoked changes in cortical cerebral hemodynamics during cycling were measured by fNIRS, which are comparable to cortical hemodynamic changes observed without exercise [131]. Notwithstanding, it is important to emphasize that further efforts are necessary to improve the signal quality of fNIRS-based brain monitoring devices, which would allow for the more reliable conclusion of the origin of observed signal changes [99].

\subsection{Which Additional Internal Load Indicators Should Be Recorded Alongside fNIRS?}

In order to quantify the state of organic systems more comprehensively, it seems useful to complement the measures of the central nervous system (e.g., $\mathrm{StO}_{2}$ in the PFC) with (easily quantifiable) measures of the autonomous nervous system. A promising indicator of the state of the autonomous nervous system is the HRV, which is operationalized by the beat-to-beat variations of the heart rate over a specific time period (e.g., during a resting state or during physical exercises) $[45,241-245]$. HRV is considered to be a proxy of the actual health state [246-249] and stress level [247,250] of an individual. HRV also reflects, at least partly, the fitness level and daily readiness [243,244,251-255] of an individual, as well as the organismic demands [256-260]. There are numerous non-linear analysis approaches to appraise HRV, which reflect the systemic character of the organism [245,248,249,261-263]. Moreover, HRV is linked to cognitive performance in specific cognitive domains (e.g., during a resting state) $[245,264-273]$ and it is, as outlined in the neurovisceral integration model, associated with the integrity of specific subareas of the PFC (e.g., medial PFC) [247,273-280]. In summary, this evidence 
suggests that HRV is a valuable parameter which should be recorded along with fNIRS in order to assess changes in the autonomic system more precisely. However, there is, to the best of our knowledge, no study available using HRV as an indicator of internal load to directly prescribe exercise intensity. Existing studies used resting-state HRV to guide the exercise prescription, but exercise intensity was prescribed with other parameters than HRV (e.g., HR or running velocity) [252,281-283].

Another parameter of interest is the pulse-respiration quotient, which provides a unique measure of the physiological state and traits [284,285] and which, therefore, should be more often assessed in physical exercise studies.

\section{Summary and Conclusion}

The optimal exercise prescription in the field of exercise-cognition is a topic of emerging interest, and a lively discussion on the matter has started. However, the question about which indicators of internal load may be the most appropriate ones remains open [15]. In this perspective article, we discuss and advocate for the use of brain-derived parameters in the exercise prescription of exercise-cognition studies (e.g., to prescribe exercise intensity). Brain-derived parameters provide the advantages that they are more closely related to the organic system that is aimed to be influenced and that they are sensitive to demands (e.g., cognitive load), which are not sufficiently reflected in conventional measures (e.g., HR). In particular, we discuss the promising potential of fNIRS-derived brain parameters (e.g., oxyHB, deoxyHb, totHb, and $\mathrm{StO}_{2}$ ) to prescribe physical exercise (e.g., exercise intensity) and we encourage the research community to test the practicability and effectiveness of this novel approach of exercise prescription.

Author Contributions: F.H. and D.H. developed the idea of the manuscript. F.H. wrote and edited the manuscript. F.H., F.S., H.Z., and D.W. created the figures. T.G., F.S., H.Z., D.W., N.G.M., and D.H. reviewed and edited the drafted versions. All authors have read and agreed to the published version of the manuscript.

Funding: This article was partially supported by the joint project "Autonomy in Old Age" (AiA) funded by the European Regional Development Fund (grant number: ZS/2019/07/99755; to N.G.M.). The authors are solely responsible for the work and the funders had no role in the preparation of the manuscript, the analysis of the studies, and the decision to publish.

Acknowledgments: The authors have nothing to acknowledge.

Conflicts of Interest: The authors have no conflict of interest to disclose.

\section{References}

1. Hillman, C.H.; Erickson, K.I.; Kramer, A.F. Be smart, exercise your heart: Exercise effects on brain and cognition. Nat. Rev. Neurosci. 2008, 9, 58-65. [CrossRef] [PubMed]

2. Liu-Ambrose, T.; Barha, C.; Best, J.R. Physical activity for brain health in older adults. Appl. Physiol. Nutr. Metab. 2018, 43, 1105-1112. [CrossRef] [PubMed]

3. Erickson, K.I.; Hillman, C.; Stillman, C.M.; Ballard, R.M.; Bloodgood, B.; Conroy, D.E.; Macko, R.; Marquez, D.X.; Petruzzello, S.J.; Powell, K.E.; et al. Physical Activity, Cognition, and Brain Outcomes. Med. Sci. Sports Exerc. 2019, 51, 1242-1251. [CrossRef] [PubMed]

4. Jackson, P.; Pialoux, V.; Corbett, D.; Drogos, L.; Erickson, K.I.; Eskes, G.A.; Poulin, M.J. Promoting brain health through exercise and diet in older adults: A physiological perspective. J. Physiol. 2016, 594, 4485-4498. [CrossRef]

5. Tyndall, A.V.; Clark, C.M.; Anderson, T.J.; Hogan, D.B.; Hill, M.D.; Longman, R.S.; Poulin, M.J. Protective Effects of Exercise on Cognition and Brain Health in Older Adults. Exerc. Sport Sci. Rev. 2018, 46, $215-223$. [CrossRef]

6. Liu-Ambrose, T.; Best, J.R. Exercise is Medicine for the Aging Brain. Kinesiol. Rev. 2017, 6, 22-29. [CrossRef]

7. Stillman, C.M.; Esteban-Cornejo, I.; Brown, B.; Bender, C.M.; Erickson, K.I. Effects of Exercise on Brain and Cognition Across Age Groups and Health States. Trends Neurosci. 2020. [CrossRef] [PubMed]

8. Esteban-Cornejo, I.; Tejero-González, C.M.; Sallis, J.F.; Veiga, O.L. Physical activity and cognition in adolescents: A systematic review. J. Sci. Med. Sport 2015, 18, 534-539. [CrossRef] 
9. Greeff, J.W.D.; Bosker, R.J.; Oosterlaan, J.; Visscher, C.; Hartman, E. Effects of physical activity on executive functions, attention and academic performance in preadolescent children: A meta-analysis. J. Sci. Med. Sport 2018, 21, 501-507. [CrossRef]

10. Hillman, C.H.; Logan, N.E.; Shigeta, T.T. A Review of Acute Physical Activity Effects on Brain and Cognition in Children. Transl. J. Acsm 2019, 17, 132-136. [CrossRef]

11. Ludyga, S.; Gerber, M.; Pühse, U.; Looser, V.N.; Kamijo, K. Systematic review and meta-analysis investigating moderators of long-term effects of exercise on cognition in healthy individuals. Nat. Hum. Behav. 2020, 1-10. [CrossRef] [PubMed]

12. Stillman, C.M.; Cohen, J.; Lehman, M.E.; Erickson, K.I. Mediators of Physical Activity on Neurocognitive Function: A Review at Multiple Levels of Analysis. Front. Hum. Neurosci. 2016, 10, 626. [CrossRef]

13. Stimpson, N.J.; Davison, G.; Javadi, A.-H. Joggin' the Noggin: Towards a Physiological Understanding of Exercise-Induced Cognitive Benefits. Neurosci. Biobehav. Rev. 2018, 88, 177-186. [CrossRef] [PubMed]

14. Herold, F.; Hamacher, D.; Schega, L.; Müller, N.G. Thinking While Moving or Moving While Thinking-Concepts of Motor-Cognitive Training for Cognitive Performance Enhancement. Front. Aging Neurosci. 2018, 10, 228. [CrossRef]

15. Herold, F.; Müller, P.; Gronwald, T.; Müller, N.G. Dose-Response Matters!-A Perspective on the Exercise Prescription in Exercise-Cognition Research. Front. Psychol. 2019, 10, 2338. [CrossRef]

16. Rolland, Y.; Van Kan, G.A.; Vellas, B. Healthy Brain Aging: Role of Exercise and Physical Activity. Clin. Geriatr. Med. 2010, 26, 75-87. [CrossRef]

17. Bherer, L.; Erickson, K.I.; Liu-Ambrose, T. A Review of the Effects of Physical Activity and Exercise on Cognitive and Brain Functions in Older Adults. J. Aging Res. 2013, 2013, 1-8. [CrossRef]

18. Voelcker-Rehage, C.; Niemann, C. Structural and functional brain changes related to different types of physical activity across the life span. Neurosci. Biobehav. Rev. 2013, 37, 2268-2295. [CrossRef]

19. Lauenroth, A.; Ioannidis, A.E.; Teichmann, B. Influence of combined physical and cognitive training on cognition: A systematic review. BMC Geriatr. 2016, 16, 141. [CrossRef]

20. Cai, Y.; Abrahamson, K. Does Exercise Impact Cognitive Performance Research Article Op in Community-dwelling Older Adults with Mild Cognitive Impairment? A Systematic Review. Qual. Prim. Care 2015, 23, 214-222.

21. Tait, J.; Duckham, R.L.; Milte, C.M.; Main, L.C.; Daly, R.M. Influence of Sequential vs. Simultaneous Dual-Task Exercise Training on Cognitive Function in Older Adults. Front. Aging Neurosci. 2017, 9, 368. [CrossRef]

22. Herold, F.; Törpel, A.; Schega, L.; Müller, N.G. Functional and/or structural brain changes in response to resistance exercises and resistance training lead to cognitive improvements-Asystematic review. Eur. Rev. Aging Phys. Act. 2019, 16, 10. [CrossRef]

23. Soga, K.; Masaki, H.; Gerber, M.; Ludyga, S. Acute and Long-term Effects of Resistance Training on Executive Function. J. Cogn. Enhanc. 2018, 2, 200-207. [CrossRef]

24. Wollesen, B.; Voelcker-Rehage, C. Training effects on motor-cognitive dual-task performance in older adults. Eur. Rev. Aging Phys. Act. 2013, 11, 5-24. [CrossRef]

25. Gronwald, T.; Budde, H. Commentary: Physical Exercise as Personalized Medicine for Dementia Prevention? Front. Physiol. 2019, 10, 1358. [CrossRef] [PubMed]

26. Hofmann, P.; Tschakert, G. Special Needs to Prescribe Exercise Intensity for Scientific Studies. Cardiol. Res. Pract. 2010, 2011, 1-10. [CrossRef] [PubMed]

27. Mann, T.N.; Lamberts, R.P.; Lambert, M. Methods of Prescribing Relative Exercise Intensity: Physiological and Practical Considerations. Sports Med. 2013, 43, 613-625. [CrossRef] [PubMed]

28. Gass, G.C.; McLellan, T.M.; Gass, E.M. Effects of prolonged exercise at a similar percentage of maximal oxygen consumption in trained and untrained subjects. Eur. J. Appl. Physiol. Occup. Physiol. 1991, 63, 430-435. [CrossRef]

29. Katch, V.; Weltman, A.; Sady, S.; Freedson, P. Validity of the relative percent concept for equating training intensity. Eur. J. Appl. Physiol. Occup. Physiol. 1978, 39, 219-227. [CrossRef]

30. Meyer, T.; Gabriel, H.H.; Kindermann, W. Is determination of exercise intensities as percentages of VO2max or HRmax adequate? Med. Sci. Sports Exerc. 1999, 31, 1342-1345. [CrossRef]

31. Scharhag-Rosenberger, F.; Meyer, T.; Gäßler, N.; Faude, O.; Kindermann, W. Exercise at given percentages of VO2max: Heterogeneous metabolic responses between individuals. J. Sci. Med. Sport 2010, 13, 74-79. [CrossRef] 
32. Weltman, A.; Weltman, J.; Rutt, R.; Seip, R.; Levine, S.; Snead, D.; Kaiser, D.; Rogol, A. Percentages of Maximal Heart Rate, Heart Rate Reserve, and VO2peak for Determining Endurance Training Intensity in Sedentary Women*. Int. J. Sports Med. 1989, 10, 212-216. [CrossRef] [PubMed]

33. Weltman, A.; Snead, D.; Seip, R.; Schurrer, R.; Weltman, J.; Rutt, R.; Rogol, A. Percentages of Maximal Heart Rate, Heart Rate Reserve and VO 2 max for Determining Endurance Training Intensity in Male Runners. Int. J. Sports Med. 1990, 11, 218-222. [CrossRef]

34. Weatherwax, R.; Harris, N.; Kilding, A.E.; Dalleck, L. The incidence of training responsiveness to cardiorespiratory fitness and cardiometabolic measurements following individualized and standardized exercise prescription: Study protocol for a randomized controlled trial. Trials 2016, 17, 601. [CrossRef]

35. Tschakert, G.; Hofmann, P. High-Intensity Intermittent Exercise: Methodological and Physiological Aspects. Int. J. Sports Physiol. Perform. 2013, 8, 600-610. [CrossRef] [PubMed]

36. Schneider, J.; Schlüter, K.; Sprave, T.; Wiskemann, J.; Rosenberger, F. Exercise intensity prescription in cancer survivors: Ventilatory and lactate thresholds are useful submaximal alternatives to VO2peak. Support. Care Cancer 2020, 1-8. [CrossRef]

37. Gronwald, T.; Velasques, B.; Ribeiro, P.; Machado, S.; Murillo-Rodríguez, E.; Ludyga, S.; Yamamoto, T.; Budde, H. Increasing exercise's effect on mental health: Exercise intensity does matter. Proc. Natl. Acad. Sci. USA 2018, 115, E11890-E11891. [CrossRef]

38. Suwabe, K.; Byun, K.; Hyodo, K.; Reagh, Z.M.; Roberts, J.M.; Matsushita, A.; Saotome, K.; Ochi, G.; Fukuie, T.; Suzuki, K.; et al. Reply to Gronwald et al.: Exercise intensity does indeed matter; maximal oxygen uptake is the gold-standard indicator. Proc. Natl. Acad. Sci. USA 2018, 115, E11892-E11893. [CrossRef]

39. Gronwald, T.; Alves, A.C.D.B.; Murillo-Rodríguez, E.; Latini, A.; Schuette, J.; Budde, H. Standardization of exercise intensity and consideration of a dose-response is essential. Commentary on "Exercise-linked FNDC5/irisin rescues synaptic plasticity and memory defects in Alzheimer's models", by Lourenco et al., published 2019 in Nature Medicine. J. Sport Health Sci. 2019, 8, 353-354. [CrossRef]

40. Burgess, D.J. The Research Doesn't Always Apply: Practical Solutions to Evidence-Based Training-Load Monitoring in Elite Team Sports. Int. J. Sports Physiol. Perform. 2017, 12, S2136-S2141. [CrossRef]

41. Bourdon, P.C.; Cardinale, M.; Murray, A.; Gastin, P.; Kellmann, M.; Varley, M.; Gabbett, T.J.; Coutts, A.J.; Burgess, D.J.; Gregson, W.; et al. Monitoring Athlete Training Loads: Consensus Statement. Int. J. Sports Physiol. Perform. 2017, 12, S2161-S2170. [CrossRef] [PubMed]

42. McLaren, S.J.; MacPherson, T.; Coutts, A.J.; Hurst, C.; Spears, I.R.; Weston, M. The Relationships Between Internal and External Measures of Training Load and Intensity in Team Sports: A Meta-Analysis. Sports Med. 2017, 48, 641-658. [CrossRef]

43. Vanrenterghem, J.; Nedergaard, N.J.; Robinson, M.A.; Drust, B. Training Load Monitoring in Team Sports: A Novel Framework Separating Physiological and Biomechanical Load-Adaptation Pathways. Sports Med. 2017, 47, 2135-2142. [CrossRef] [PubMed]

44. Wallace, L.K.; Slattery, K.; Coutts, A.J. The Ecological Validity and Application of the Session-RPE Method for Quantifying Training Loads in Swimming. J. Strength Cond. Res. 2009, 23, 33-38. [CrossRef] [PubMed]

45. Halson, S. Monitoring training load to understand fatigue in athletes. Sports Med. 2014, 44, S139-S147. [CrossRef]

46. Impellizzeri, F.M.; Marcora, S.M.; Coutts, A.J. Internal and External Training Load: 15 Years On. Int. J. Sports Physiol. Perform. 2019, 14, 270-273. [CrossRef]

47. Soligard, T.; Schwellnus, M.; Alonso, J.-M.; Bahr, R.; Clarsen, B.; Dijkstra, H.P.; Gabbett, T.; Gleeson, M.; Hägglund, M.; Hutchinson, M.R.; et al. How much is too much? (Part 1) International Olympic Committee consensus statement on load in sport and risk of injury. Br. J. Sports Med. 2016, 50, 1030-1041. [CrossRef]

48. Maslov, P.Z.; Schulman, A.; Lavie, C.J.; Narula, J. Personalized exercise dose prescription. Eur. Heart J. 2017, 39, 2346-2355. [CrossRef]

49. Pickering, C.; Kiely, J. Do Non-Responders to Exercise Exist-And If So, What Should We Do About Them? Sports Med. 2018, 49, 1-7. [CrossRef]

50. Perrey, S.; Besson, P. Studying brain activity in sports performance: Contributions and issues. Prog. Brain Res. 2018, 240, 247-267. [CrossRef]

51. Tan, S.J.; Kerr, G.; Sullivan, J.P.; Peake, J.M. A Brief Review of the Application of Neuroergonomics in Skilled Cognition During Expert Sports Performance. Front. Hum. Neurosci. 2019, 13, 278. [CrossRef] [PubMed] 
52. Wang, C.-H.; Moreau, D.; Kao, S.-C. From the Lab to the Field: Potential Applications of Dry EEG Systems to Understand the Brain-Behavior Relationship in Sports. Front. Mol. Neurosci. 2019, 13, 893. [CrossRef] [PubMed]

53. Peake, J.M.; Kerr, G.; Sullivan, J.P. A Critical Review of Consumer Wearables, Mobile Applications, and Equipment for Providing Biofeedback, Monitoring Stress, and Sleep in Physically Active Populations. Front. Physiol. 2018, 9, 743. [CrossRef] [PubMed]

54. Cohen, M.X. Where Does EEG Come From and What Does It Mean? Trends Neurosci. 2017, 40, $208-218$. [CrossRef]

55. Yucel, M.; Selb, J.J.; Huppert, T.J.; Franceschini, M.A.; Boas, D. Functional Near Infrared Spectroscopy: Enabling routine functional brain imaging. Curr. Opin. Biomed. Eng. 2017, 4, 78-86. [CrossRef]

56. Rahman, M.; Karwowski, W.; Fafrowicz, M.; Hancock, P.A. Neuroergonomics Applications of Electroencephalography in Physical Activities: A Systematic Review. Front. Hum. Neurosci. 2019, 13, 182. [CrossRef]

57. Hülsdünker, T.; Mierau, A.; Neeb, C.; Kleinöder, H.; Strüder, H. Cortical processes associated with continuous balance control as revealed by EEG spectral power. Neurosci. Lett. 2015, 592, 1-5. [CrossRef]

58. Collado-Mateo, D.; Adsuar, J.C.; Olivares, P.R.; Cano-Plasencia, R.; Gusi, N. Using a dry electrode EEG device during balance tasks in healthy young-adult males: Test-retest reliability analysis. Somat. Mot. Res. 2015, 32, 219-226. [CrossRef]

59. Slobounov, S.; Sebastianelli, W.; Hallett, M. Residual brain dysfunction observed one year post-mild traumatic brain injury: Combined EEG and balance study. Clin. Neurophysiol. 2012, 123, 1755-1761. [CrossRef]

60. Choi, W.; Lee, S.; Park, J. EEG-biofeedback Intervention Improves balance in Stroke Survivor. Indian J. Sci. Technol. 2015, 8, 8. [CrossRef]

61. Hülsdünker, T.; Mierau, A.; Strüder, H.K. Higher Balance Task Demands are Associated with an Increase in Individual Alpha Peak Frequency. Front. Hum. Neurosci. 2016, 9, 85. [CrossRef] [PubMed]

62. Mierau, A.; Hülsdünker, T.; Strüder, H.K. Changes in cortical activity associated with adaptive behavior during repeated balance perturbation of unpredictable timing. Front. Behav. Neurosci. 2015, 9, 233. [CrossRef] [PubMed]

63. Mierau, A.; Pester, B.; Hülsdünker, T.; Schiecke, K.; Strüder, H.K.; Witte, H. Cortical Correlates of Human Balance Control. Brain Topogr. 2017, 30, 434-446. [CrossRef] [PubMed]

64. Beurskens, R.; Steinberg, F.; Antoniewicz, F.; Wolff, W.; Granacher, U. Neural Correlates of Dual-Task Walking: Effects of Cognitive versus Motor Interference in Young Adults. Neural Plast. 2016, 2016, 1-9. [CrossRef] [PubMed]

65. Bruijn, S.; Van Dieën, J.; Daffertshofer, A. Beta activity in the premotor cortex is increased during stabilized as compared to normal walking. Front. Hum. Neurosci. 2015, 9, 321. [CrossRef] [PubMed]

66. Castermans, T.; Duvinage, M.; Cheron, G.; Dutoit, T. About the cortical origin of the low-delta and high-gamma rhythms observed in EEG signals during treadmill walking. Neurosci. Lett. 2014, 561, 166-170. [CrossRef]

67. Nordin, A.D.; Hairston, W.D.; Ferris, D.P. Human electrocortical dynamics while stepping over obstacles. Sci. Rep. 2019, 9, 4693. [CrossRef]

68. Oliveira, A.S.; Schlink, B.R.; Hairston, W.D.; Konig, P.; Ferris, D.P. Restricted vision increases sensorimotor cortex involvement in human walking. J. Neurophysiol. 2017, 118, 1943-1951. [CrossRef]

69. Peterson, S.M.; Ferris, D.P. Differentiation in Theta and Beta Electrocortical Activity between Visual and Physical Perturbations to Walking and Standing Balance. eNeuro 2018, 5, 207-218. [CrossRef]

70. Flanagan, S.D.; Dunn-Lewis, C.; Comstock, B.A.; Maresh, C.M.; Volek, J.S.; Denegar, C.R.; Kraemer, W.J. Cortical Activity during a Highly-Trained Resistance Exercise Movement Emphasizing Force, Power or Volume. Brain Sci. 2012, 2, 649-666. [CrossRef]

71. Falvo, M.J.; Sirevaag, E.J.; Rohrbaugh, J.W.; Earhart, G.M. Resistance training induces supraspinal adaptations: Evidence from movement-related cortical potentials. Eur. J. Appl. Physiol. 2010, 109, 923-933. [CrossRef] [PubMed]

72. Kenville, R.; Maudrich, T.; Vidaurre, C.; Maudrich, D.; Villringer, A.; Nikulin, V.V.; Ragert, P. Corticomuscular interactions during different movement periods in a multi-joint compound movement. Sci. Rep. 2020, 10, 1-13. [CrossRef] [PubMed] 
73. Gronwald, T.; Ludyga, S.; Hottenrott, K. Einfluss einer intensiven Intervallbelastung auf die Beanspruchung der kortikalen Gehirnaktivität. Schweiz. Z. Sportmed. Sporttraumatol. 2015, 63, 23-28.

74. Gronwald, T.; Ludyga, S.; Hottenrott, K. Gehirnaktivität bei identischer Belastung-Eine standardisierte fahrradergometrische Laborstudie unter Normoxie und normbarer Hypoxie. Leistungssport 2015, 45, $42-47$.

75. Ludyga, S.; Hottenrott, K.; Gronwald, T. Einfluss verschiedener Belastungssituationen auf die EEG-Aktivität. Dtsch. Z. Sportmed. 2015, 2015, 113-120. [CrossRef]

76. Ludyga, S.; Gronwald, T.; Hottenrott, K. Do Male and Female Cyclists' Cortical Activity Differ Before and During Cycling Exercise? J. Sport Exerc. Psychol. 2015, 37, 617-625. [CrossRef]

77. Bullock, T.; Cecotti, H.; Giesbrecht, B. Multiple stages of information processing are modulated during acute bouts of exercise. Neuroscience 2015, 307, 138-150. [CrossRef]

78. Olson, R.; Chang, Y.; Brush, C.; Kwok, A.N.; Gordon, V.X.; Alderman, B. Neurophysiological and behavioral correlates of cognitive control during low and moderate intensity exercise. NeuroImage 2016, 131, 171-180. [CrossRef]

79. Storzer, L.; Butz, M.; Hirschmann, J.; Abbasi, O.; Gratkowski, M.; Saupe, D.; Schnitzler, A.; Dalal, S. Bicycling and Walking are Associated with Different Cortical Oscillatory Dynamics. Front. Hum. Neurosci. 2016, 10, 29. [CrossRef]

80. Thompson, T.; Steffert, T.; Ros, T.; Leach, J.; Gruzelier, J. EEG applications for sport and performance. Methods 2008, 45, 279-288. [CrossRef]

81. Lloyd-Fox, S.; Blasi, A.; Elwell, C. Illuminating the developing brain: The past, present and future of functional near infrared spectroscopy. Neurosci. Biobehav. Rev. 2010, 34, 269-284. [CrossRef]

82. Park, J.; Fairweather, M.M.; Donaldson, D. Making the case for mobile cognition: EEG and sports performance. Neurosci. Biobehav. Rev. 2015, 52, 117-130. [CrossRef] [PubMed]

83. Pinti, P.; Tachtsidis, I.; Hamilton, A.; Hirsch, J.; Aichelburg, C.; Gilbert, S.; Burgess, P.W.; Pinti, P. The present and future use of functional near-infrared spectroscopy (fNIRS) for cognitive neuroscience. Ann. N. Y. Acad. Sci. 2020, 1464, 5-29. [CrossRef] [PubMed]

84. Soltanlou, M.; Sitnikova, M.A.; Nuerk, H.-C.; Dresler, T. Applications of Functional Near-Infrared Spectroscopy (fNIRS) in Studying Cognitive Development: The Case of Mathematics and Language. Front. Psychol. 2018, 9, 277. [CrossRef] [PubMed]

85. Burle, B.; Spieser, L.; Roger, C.; Casini, L.; Hasbroucq, T.; Vidal, F. Spatial and temporal resolutions of EEG: Is it really black and white? A scalp current density view. Int. J. Psychophysiol. 2015, 97, 210-220. [CrossRef] [PubMed]

86. Cutini, S.; Brigadoi, S. Unleashing the future potential of functional near-infrared spectroscopy in brain sciences. J. Neurosci. Methods 2014, 232, 152-156. [CrossRef] [PubMed]

87. A Ward, J.; Pinti, P.; Amft, O.; Van Laerhoven, K. Wearables and the Brain. IEEE Pervasive Comput. 2019, 18, 94-100. [CrossRef]

88. Maskeliūnas, R.; Damaševičius, R.; Martisius, I.; Vasiljevas, M. Consumer grade EEG devices: Are they usable for control tasks? PeerJ 2016, 4, e1746. [CrossRef]

89. Pontifex, M.B.; Hillman, C.H. Neuroelectric measurement of cognition during aerobic exercise. Methods 2008, 45, 271-278. [CrossRef]

90. Symeonidou, E.-R.; Nordin, A.D.; Hairston, W.D.; Ferris, D.P. Effects of Cable Sway, Electrode Surface Area, and Electrode Mass on Electroencephalography Signal Quality during Motion. Sensors 2018, 18, 1073. [CrossRef]

91. Smith, M. Shedding light on the adult brain: A review of the clinical applications of near-infrared spectroscopy. Philos. Trans. R. Soc. A Math. Phys. Eng. Sci. 2011, 369, 4452-4469. [CrossRef] [PubMed]

92. Ekkekakis, P. Illuminating the Black Box: Investigating Prefrontal Cortical Hemodynamics during Exercise with Near-Infrared Spectroscopy. J. Sport Exerc. Psychol. 2009, 31, 505-553. [CrossRef] [PubMed]

93. Perrey, S. Non-invasive NIR spectroscopy of human brain function during exercise. Methods 2008, 45, $289-299$. [CrossRef]

94. Scarapicchia, V.; Brown, C.; Mayo, C.; Gawryluk, J. Functional Magnetic Resonance Imaging and Functional Near-Infrared Spectroscopy: Insights from Combined Recording Studies. Front. Hum. Neurosci. 2017, 11, 419. [CrossRef] 
95. Quaresima, V.; Ferrari, M. Functional Near-Infrared Spectroscopy (fNIRS) for Assessing Cerebral Cortex Function During Human Behavior in Natural/Social Situations: A Concise Review. Organ. Res. Methods 2016, 22, 46-68. [CrossRef]

96. Pinti, P.; Aichelburg, C.; Gilbert, S.; Hamilton, A.; Hirsch, J.; Burgess, P.; Tachtsidis, I. A Review on the Use of Wearable Functional Near-Infrared Spectroscopy in Naturalistic Environments. Jpn. Psychol. Res. 2018, 60, 347-373. [CrossRef]

97. Zhu, Y.; Rodriguez-Paras, C.; Rhee, J.; Mehta, R.K. Methodological Approaches and Recommendations for Functional Near-Infrared Spectroscopy Applications in HF/E Research. Hum. Factors 2019, 62, 613-642. [CrossRef]

98. Gervain, J.; Mehler, J.; Werker, J.F.; Nelson, C.A.; Csibra, G.; Lloyd-Fox, S.; Shukla, M.; Aslin, R.N. Near-infrared spectroscopy: A report from the McDonnell infant methodology consortium. Dev. Cogn. Neurosci. 2011, 1, 22-46. [CrossRef]

99. Tachtsidis, I.; Scholkmann, F. False positives and false negatives in functional near-infrared spectroscopy: Issues, challenges, and the way forward. Neurophotonics 2016, 3, 30401. [CrossRef]

100. Kirilina, E.; Jelzow, A.; Heine, A.; Niessing, M.; Wabnitz, H.; Brühl, R.; Ittermann, B.; Jacobs, A.M.; Tachtsidis, I. The physiological origin of task-evoked systemic artefacts in functional near infrared spectroscopy. NeuroImage 2012, 61, 70-81. [CrossRef] [PubMed]

101. Caldwell, M.; Scholkmann, F.; Wolf, U.; Wolf, M.; Elwell, C.; Tachtsidis, I. Modelling confounding effects from extracerebral contamination and systemic factors on functional near-infrared spectroscopy. NeuroImage 2016, 143, 91-105. [CrossRef] [PubMed]

102. Kozlová, S. The Use of Near-Infrared Spectroscopy in the Sport-Scientific Context. J. Neurol. Neurol. Disord. 2018, 4, 1. [CrossRef]

103. Seidel-Marzi, O.; Ragert, P. Neurodiagnostics in Sports: Investigating the Athlete's Brain to Augment Performance and Sport-Specific Skills. Front. Hum. Neurosci. 2020, 14, 133. [CrossRef] [PubMed]

104. Carius, D.; Andrä, C.; Clauß, M.; Ragert, P.; Bunk, M.; Mehnert, J. Hemodynamic Response Alteration As a Function of Task Complexity and Expertise-An fNIRS Study in Jugglers. Front. Hum. Neurosci. 2016, 10, 1. [CrossRef]

105. Seidel, O.; Carius, D.; Kenville, R.; Ragert, P. Motor learning in a complex balance task and associated neuroplasticity: A comparison between endurance athletes and nonathletes. J. Neurophysiol. 2017, 118, 1849-1860. [CrossRef]

106. Herold, F.; Orlowski, K.; Börmel, S.; Müller, N.G. Cortical activation during balancing on a balance board. Hum. Mov. Sci. 2017, 51, 51-58. [CrossRef]

107. Fujimoto, H.; Mihara, M.; Hattori, N.; Hatakenaka, M.; Kawano, T.; Yagura, H.; Miyai, I.; Mochizuki, H. Cortical changes underlying balance recovery in patients with hemiplegic stroke. NeuroImage 2014, 85, 547-554. [CrossRef]

108. Fujimoto, H.; Mihara, M.; Hattori, N.; Hatakenaka, M.; Yagura, H.; Kawano, T.; Miyai, I.; Mochizuki, H. Neurofeedback-induced facilitation of the supplementary motor area affects postural stability. Neurophotonics 2017, 4, 1. [CrossRef]

109. Mihara, M.; Miyai, I.; Hatakenaka, M.; Kubota, K.; Sakoda, S. Role of the prefrontal cortex in human balance control. NeuroImage 2008, 43, 329-336. [CrossRef]

110. Mihara, M.; Miyai, I.; Hattori, N.; Hatakenaka, M.; Yagura, H.; Kawano, T.; Kubota, K. Cortical control of postural balance in patients with hemiplegic stroke. NeuroReport 2012, 23, 314-319. [CrossRef]

111. Herold, F.; Wiegel, P.; Scholkmann, F.; Thiers, A.; Hamacher, D.; Schega, L. Functional near-infrared spectroscopy in movement science: A systematic review on cortical activity in postural and walking tasks. Neurophotonics 2017, 4, 41403. [CrossRef]

112. Vitório, R.; Stuart, S.; Rochester, L.; Alcock, L.; Pantall, A. fNIRS response during walking-Artefact or cortical activity? A systematic review. Neurosci. Biobehav. Rev. 2017, 83, 160-172. [CrossRef] [PubMed]

113. Formenti, D.; Perpetuini, D.; Iodice, P.; Cardone, D.; Michielon, G.; Scurati, R.; Alberti, G.; Merla, A. Effects of knee extension with different speeds of movement on muscle and cerebral oxygenation. PeerJ 2018, 6, e5704. [CrossRef]

114. Borot, L.; Vergotte, G.; Perrey, S. Different Hemodynamic Responses of the Primary Motor Cortex Accompanying Eccentric and Concentric Movements: A Functional NIRS Study. Brain Sci. 2018, 8, 75. [CrossRef] 
115. Kenville, R.; Maudrich, T.; Carius, D.; Ragert, P. Hemodynamic Response Alterations in Sensorimotor Areas as a Function of Barbell Load Levels during Squatting: An fNIRS Study. Front. Hum. Neurosci. 2017, 11, 268. [CrossRef] [PubMed]

116. Cavuoto, L.A.; Maikala, R.V. Role of obesity on cerebral hemodynamics and cardiorespiratory responses in healthy men during repetitive incremental lifting. Eur. J. Appl. Physiol. 2015, 115, 1905-1917. [CrossRef]

117. Ono, Y.; Noah, J.A.; Zhang, X.; Nomoto, Y.; Suzuki, T.; Shimada, S.; Tachibana, A.; Bronner, S.; Hirsch, J. Motor learning and modulation of prefrontal cortex: An fNIRS assessment. J. Neural Eng. 2015, 12, 66004. [CrossRef]

118. Noah, J.A.; Ono, Y.; Nomoto, Y.; Shimada, S.; Tachibana, A.; Zhang, X.; Bronner, S.; Hirsch, J. fMRI Validation of fNIRS Measurements During a Naturalistic Task. J. Vis. Exp. 2015, 100, e52116. [CrossRef]

119. Tachibana, A.; Noah, J.A.; Bronner, S.; Ono, Y.; Onozuka, M. Parietal and temporal activity during a multimodal dance video game: An fNIRS study. Neurosci. Lett. 2011, 503, 125-130. [CrossRef]

120. Lu, X.; Hui-Chan, C.W.-Y.; Tsang, W.W.N. Changes of heart rate variability and prefrontal oxygenation during Tai Chi practice versus arm ergometer cycling. J. Phys. Sci. 2016, 28, 3243-3248. [CrossRef]

121. Tsang, W.W.N.; Chan, K.; Cheng, C.N.; Hu, F.S.; Mak, C.T.; Wong, J.W. Tai Chi practice on prefrontal oxygenation levels in older adults: A pilot study. Complement. Med. 2019, 42, 132-136. [CrossRef] [PubMed]

122. Carius, D.; Hörnig, L.; Ragert, P.; Kaminski, E. Characterizing cortical hemodynamic changes during climbing and its relation to climbing expertise. Neurosci. Lett. 2019, 715, 134604. [CrossRef] [PubMed]

123. Jones, B.; Cooper, C.E. Near Infrared Spectroscopy (NIRS) Observation of Vastus Lateralis (Muscle) and Prefrontal Cortex (Brain) Tissue Oxygenation During Synchronised Swimming Routines in Elite Athletes. Adv. Exp. Med. Biol. 2018, 1072, 111-117. [CrossRef]

124. Balardin, J.B.; Morais, G.A.Z.; Furucho, R.A.; Trambaiolli, L.; Vanzella, P.; Biazoli, C.E.; Sato, J.R. Imaging Brain Function with Functional Near-Infrared Spectroscopy in Unconstrained Environments. Front. Hum. Neurosci. 2017, 11, 258. [CrossRef] [PubMed]

125. Santos-Concejero, J.; Billaut, F.; Grobler, L.; Oliván, J.; Noakes, T.D.; Tucker, R. Maintained cerebral oxygenation during maximal self-paced exercise in elite Kenyan runners. J. Appl. Physiol. 2015, 118, 156-162. [CrossRef] [PubMed]

126. Santos-Concejero, J.; Billaut, F.; Grobler, L.; Oliván, J.; Noakes, T.D.; Tucker, R. Brain oxygenation declines in elite Kenyan runners during a maximal interval training session. Eur. J. Appl. Physiol. 2017, 117, 1017-1024. [CrossRef]

127. Suzuki, M.; Miyai, I.; Ono, T.; Oda, I.; Konishi, I.; Kochiyama, T.; Kubota, K. Prefrontal and premotor cortices are involved in adapting walking and running speed on the treadmill: An optical imaging study. NeuroImage 2004, 23, 1020-1026. [CrossRef]

128. Seidel, O.; Carius, D.; Roediger, J.; Rumpf, S.; Ragert, P. Changes in neurovascular coupling during cycling exercise measured by multi-distance fNIRS: A comparison between endurance athletes and physically active controls. Exp. Brain Res. 2019, 237, 2957-2972. [CrossRef]

129. Tempest, G.; Parfitt, G. Self-reported tolerance influences prefrontal cortex hemodynamics and affective responses. Cogn. Affect. Behav. Neurosci. 2015, 16, 63-71. [CrossRef]

130. Tempest, G.; Davranche, K.; Brisswalter, J.; Perrey, S.; Radel, R. The differential effects of prolonged exercise upon executive function and cerebral oxygenation. Brain Cogn. 2017, 113, 133-141. [CrossRef]

131. Tempest, G.; Reiss, A.L. The Utility of Functional Near-infrared Spectroscopy for Measuring Cortical Activity during Cycling Exercise. Med. Sci. Sports Exerc. 2019, 51, 979-987. [CrossRef]

132. Ando, S.; Hatamoto, Y.; Sudo, M.; Kiyonaga, A.; Tanaka, H.; Higaki, Y. The Effects of Exercise Under Hypoxia on Cognitive Function. PLoS ONE 2013, 8, e63630. [CrossRef] [PubMed]

133. Ando, S.; Kokubu, M.; Yamada, Y.; Kimura, M. Does cerebral oxygenation affect cognitive function during exercise? Eur. J. Appl. Physiol. 2011, 111, 1973-1982. [CrossRef] [PubMed]

134. Asahara, R.; Endo, K.; Liang, N.; Matsukawa, K. An increase in prefrontal oxygenation at the start of voluntary cycling exercise was observed independently of exercise effort and muscle mass. Eur. J. Appl. Physiol. 2018, 118, 1689-1702. [CrossRef] [PubMed]

135. Asahara, R.; Matsukawa, K.; Ishii, K.; Liang, N.; Endo, K. The prefrontal oxygenation and ventilatory responses at start of one-legged cycling exercise have relation to central command. J. Appl. Physiol. 2016, 121, 1115-1126. [CrossRef] 
136. Billaut, F.; Davis, J.M.; Smith, K.; Marino, F.E.; Noakes, T.D. Cerebral oxygenation decreases but does not impair performance during self-paced, strenuous exercise. Acta Physiol. 2010, 198, 477-486. [CrossRef]

137. Gayda, M.; Lapierre, G.; Dupuy, O.; Fraser, S.; Bherer, L.; Juneau, M.; Gremeaux, V.; Nigam, A. Cardiovascular and cerebral hemodynamics during exercise and recovery in obese individuals as a function of their fitness status. Physiol. Rep. 2017, 5, e13321. [CrossRef]

138. Gayda, M.; Grémeaux, V.; Bherer, L.; Juneau, M.; Drigny, J.; Dupuy, O.; Lapierre, G.; Labelle, V.; Fortier, A.; Nigam, A. Cognitive function in patients with stable coronary heart disease: Related cerebrovascular and cardiovascular responses. PLoS ONE 2017, 12, e0183791. [CrossRef]

139. Giles, G.E.; Brunyé, T.T.; Eddy, M.D.; Mahoney, C.R.; Gagnon, S.A.; Taylor, H.A.; Kanarek, R.B. Acute exercise increases oxygenated and deoxygenated hemoglobin in the prefrontal cortex. Neuroreport 2014, 25, 1320-1325. [CrossRef]

140. González-Alonso, J.; Dalsgaard, M.K.; Osada, T.; Volianitis, S.; Dawson, E.A.; Yoshiga, C.C.; Secher, N.H. Brain and central haemodynamics and oxygenation during maximal exercise in humans. J. Physiol. 2004, 557, 331-342. [CrossRef]

141. Jung, R.; Moser, M.; Baucsek, S.; Dern, S.; Schneider, S. Activation patterns of different brain areas during incremental exercise measured by near-infrared spectroscopy. Exp. Brain Res. 2015, 233, 1175-1180. [CrossRef] [PubMed]

142. Kan, B.; Speelman, C.; Nosaka, K. Cognitive demand of eccentric versus concentric cycling and its effects on post-exercise attention and vigilance. Eur. J. Appl. Physiol. 2019, 119, 1599-1610. [CrossRef] [PubMed]

143. Lin, S.-I.; Lin, P.-Y.; Chen, J.-J.J. The cortical control of cycling exercise in stroke patients: An fNIRS study. Hum. Brain Mapp. 2012, 34, 2381-2390. [CrossRef] [PubMed]

144. Ohyanagi, H.; Tsubaki, A.; Morishita, S.; Obata, H.; Qin, W.; Onishi, H. Changes in the Prefrontal Cortex Oxygenation Levels During Cycling in the Supine and Upright Positions. Adv. Exp. Med. Biol. 2018, 1072, 133-137. [CrossRef]

145. Quinn, K.; Billaut, F.; Bulmer, A.C.; Minahan, C.L. Cerebral oxygenation declines but does not impair peak oxygen uptake during incremental cycling in women using oral contraceptives. Eur. J. Appl. Physiol. 2018, 118, 2417-2427. [CrossRef] [PubMed]

146. Radel, R.; Tempest, G.; Brisswalter, J. The long and winding road: Effects of exercise intensity and type upon sustained attention. Physiol. Behav. 2018, 195, 82-89. [CrossRef] [PubMed]

147. Schmit, C.; Davranche, K.; Easthope, C.S.; Colson, S.S.; Brisswalter, J.; Radel, R. Pushing to the limits: The dynamics of cognitive control during exhausting exercise. Neuropsychologia 2015, 68, 71-81. [CrossRef] [PubMed]

148. Takehara, N.; Tsubaki, A.; Yamazaki, Y.; Kanaya, C.; Sato, D.; Morishita, S.; Onishi, H. Changes in Oxyhemoglobin Concentration in the Prefrontal Cortex and Primary Motor Cortex During Low- and Moderate-Intensity Exercise on a Cycle Ergometer. Adv. Exp. Med. Biol. 2017, 977, 241-247. [CrossRef]

149. Tsubaki, A.; Morishita, S.; Tokunaga, Y.; Sato, D.; Tamaki, H.; Yamazaki, Y.; Qin, W.; Onishi, H. Changes in Cerebral Oxyhaemoglobin Levels During and After a Single 20-Minute Bout of Moderate-Intensity Cycling. Adv. Exp. Med. Biol. 2018, 1072, 127-131. [CrossRef]

150. Tsubaki, A.; Morishita, S.; Tokunaga, Y.; Sato, D.; Qin, W.; Kojima, S.; Onishi, H. Laterality of cortical oxygenation in the prefrontal cortex during $20 \mathrm{~min}$ of moderate-intensity cycling exercise: A near-infrared spectroscopy study. Ann. Phys. Rehabil. Med. 2018, 61, e460. [CrossRef]

151. Tsubaki, A.; Takai, H.; Oyanagi, K.; Kojima, S.; Tokunaga, Y.; Miyaguchi, S.; Sugawara, K.; Sato, D.; Tamaki, H.; Onishi, H. Correlation Between the Cerebral Oxyhaemoglobin Signal and Physiological Signals During Cycling Exercise: A Near-Infrared Spectroscopy Study. Adv. Exp. Med. Biol. 2016, 923, 159-166. [CrossRef] [PubMed]

152. Tsubaki, A.; Takehara, N.; Sato, D.; Morishita, S.; Tokunaga, Y.; Sugawara, K.; Kojima, S.; Tamaki, H.; Yamazaki, Y.; Onishi, H. Cortical Oxyhemoglobin Elevation Persists After Moderate-Intensity Cycling Exercise: A Near-Infrared Spectroscopy Study. Adv. Exp. Med. Biol. 2017, 977, 261-268. [CrossRef]

153. Piper, S.K.; Krueger, A.; Koch, S.P.; Mehnert, J.; Habermehl, C.; Steinbrink, J.; Obrig, H.; Schmitz, C.H. A wearable multi-channel fNIRS system for brain imaging in freely moving subjects. NeuroImage 2013, 85, 64-71. [CrossRef] 
154. Kojima, S.; Morishita, S.; Qin, W.; Tsubaki, A. Cerebral Oxygenation Dynamics of the Prefrontal Cortex and Motor-Related Area During Cardiopulmonary Exercise Test: A Near-Infrared Spectroscopy Study. Adv. Exp. Med. Biol. 2020, 1232, 231-237. [CrossRef] [PubMed]

155. Tsubaki, A.; Morishita, S.; Tokunaga, Y.; Sato, D.; Qin, W.; Kojima, S.; Onishi, H. Effect of Exercise Duration on Post-Exercise Persistence of Oxyhemoglobin Changes in the Premotor Cortex: A Near-Infrared Spectroscopy Study in Moderate-Intensity Cycling Exercise. Adv. Exp. Med. Biol. 2020, 1232, 193-199. [CrossRef] [PubMed]

156. Stevens, D.; Halaki, M.; Chow, C.; O’Dwyer, N. The effects of multi-stage exercise with and without concurrent cognitive performance on cardiorespiratory and cerebral haemodynamic responses. Eur. J. Appl. Physiol. 2018, 118, 2121-2132. [CrossRef] [PubMed]

157. Subudhi, A.W.; Lorenz, M.C.; Fulco, C.S.; Roach, R.C. Cerebrovascular responses to incremental exercise during hypobaric hypoxia: Effect of oxygenation on maximal performance. Am. J. Physiol. Heart Circ. Physiol. 2008, 294, H164-H171. [CrossRef]

158. Subudhi, A.W.; Miramon, B.R.; Granger, M.E.; Roach, R.C. Frontal and motor cortex oxygenation during maximal exercise in normoxia and hypoxia. J. Appl. Physiol. 2009, 106, 1153-1158. [CrossRef]

159. Subudhi, A.W.; Dimmen, A.C.; Roach, R.C. Effects of acute hypoxia on cerebral and muscle oxygenation during incremental exercise. J. Appl. Physiol. 2007, 103, 177-183. [CrossRef]

160. Cavuoto, L.A.; Maikala, R.V. Obesity and the Role of Short Duration Submaximal Work on Cardiovascular and Cerebral Hemodynamics. PLoS ONE 2016, 11, e0153826. [CrossRef]

161. Imhoff, S.; Malenfant, S.; Nadreau, É.; Poirier, P.; Bailey, D.M.; Brassard, P. Uncoupling between cerebral perfusion and oxygenation during incremental exercise in an athlete with postconcussion syndrome: A case report. Physiol. Rep. 2017, 5, e13131. [CrossRef]

162. Marillier, M.; Gruet, M.; Baillieul, S.; Wuyam, B.; Tamisier, R.; Levy, P.A.; Pépin, J.-L.; Verges, S. Impaired cerebral oxygenation and exercise tolerance in patients with severe obstructive sleep apnea syndrome. Sleep Med. 2018, 51, 37-46. [CrossRef] [PubMed]

163. Neary, J.P.; Roberts, A.D.W.; Leavins, N.; Harrison, M.F.; Croll, J.C.; Sexsmith, J.R. Prefrontal cortex oxygenation during incremental exercise in chronic fatigue syndrome. Clin. Physiol. Funct. Imaging 2008, 28, 364-372. [CrossRef] [PubMed]

164. Seifert, T.; Rasmussen, P.; Secher, N.H.; Nielsen, H.B. Cerebral oxygenation decreases during exercise in humans with beta-adrenergic blockade. Acta Physiol. 2009, 196, 295-302. [CrossRef] [PubMed]

165. Tempest, G.; Eston, R.G.; Parfitt, G. Prefrontal Cortex Haemodynamics and Affective Responses during Exercise: A Multi-Channel Near Infrared Spectroscopy Study. PLoS ONE 2014, 9, e95924. [CrossRef] [PubMed]

166. Koike, A.; Itoh, H.; Oohara, R.; Hoshimoto, M.; Tajima, A.; Aizawa, T.; Fu, L.T. Cerebral oxygenation during exercise in cardiac patients. Chest 2004, 125, 182-190. [CrossRef]

167. Huang, S.-C.; Chen, C.P.; Fu, T.-C.; Chen, Y.-J. Integration of Brain Tissue Saturation Monitoring in Cardiopulmonary Exercise Testing in Patients with Heart Failure. J. Vis. Exp. 2019, 152, e60289. [CrossRef]

168. Chen, Y.-J.; Wang, J.-S.; Hsu, C.-C.; Lin, P.-J.; Tsai, F.-C.; Wen, M.-S.; Kuo, C.-T.; Huang, S.-C. Cerebral desaturation in heart failure: Potential prognostic value and physiologic basis. PLoS ONE 2018, 13, e0196299. [CrossRef]

169. Koike, A.; Hoshimoto, M.; Tajima, A.; Nagayama, O.; Yamaguchi, K.; Goda, A.; Yamashita, T.; Sagara, K.; Itoh, H.; Aizawa, T. Critical level of cerebral oxygenation during exercise in patients with left ventricular dysfunction. Circ. J. 2006, 70, 1457-1461. [CrossRef]

170. Liao, L.-D.; Tsytsarev, V.; Delgado-Martínez, I.; Li, M.-L.; Erzurumlu, R.; Vipin, A.; Orellana, J.; Lin, Y.-R.; Lai, H.-Y.; Chen, Y.-Y.; et al. Neurovascular coupling: In vivo optical techniques for functional brain imaging. Biomed. Eng. Online 2013, 12, 38. [CrossRef]

171. Scholkmann, F.; Kleiser, S.; Metz, A.J.; Zimmermann, R.; Pavia, J.M.; Wolf, U.; Wolf, M. A review on continuous wave functional near-infrared spectroscopy and imaging instrumentation and methodology. NeuroImage 2014, 85, 6-27. [CrossRef] [PubMed]

172. Lindauer, U.; Dirnagl, U.; Füchtemeier, M.; Böttiger, C.; Offenhauser, N.; Leithner, C.; Royl, G. Pathophysiological Interference with Neurovascular Coupling-When Imaging Based on Hemoglobin Might Go Blind. Front. Neuroenerg. 2010, 2, 2. [CrossRef] [PubMed] 
173. León-Carrión, J.; León-Domniguez, U. Functional Near-Infrared Spectroscopy (fNIRS): Principles and Neuroscientific Applications. In Neuroimaging—Methods; Bright, P., Ed.; InTech: Rijeka, Croatia, 2017; pp. 48-74. ISBN 978-953-51-0097-3.

174. Scholkmann, F.; Wolf, M. Measuring brain activity using functional near infrared spectroscopy: A short review. Spectrosc. Eur. 2012, 24, 6-10.

175. Nippert, A.R.; Biesecker, K.R.; Newman, E.A. Mechanisms Mediating Functional Hyperemia in the Brain. Neuroscientist 2017, 24, 73-83. [CrossRef] [PubMed]

176. Herold, F.; Wiegel, P.; Scholkmann, F.; Müller, N.G. Applications of Functional Near-Infrared Spectroscopy (fNIRS) Neuroimaging in Exercise-Cognition Science: A Systematic, Methodology-Focused Review. J. Clin. Med. 2018, 7, 466. [CrossRef]

177. Bunce, S.; Izzetoglu, M.; Izzetoglu, K.; Onaral, B.; Pourrezaei, K. Functional near-infrared spectroscopy. IEEE Eng. Med. Boil. Mag. 2006, 25, 54-62. [CrossRef]

178. Izzetoglu, M.; Bunce, S.C.; Izzetoglu, K.; Onaral, B.; Pourrezaei, A.K. Functional brain imaging using near-infrared technology. IEEE Eng. Med. Boil. Mag. 2007, 26, 38-46. [CrossRef]

179. Obrig, H.; Wenzel, R.; Kohl, M.; Horst, S.; Wobst, P.; Steinbrink, J.; Thomas, F.; Villringer, A. Near-infrared spectroscopy: Does it function in functional activation studies of the adult brain? Int. J. Psychophysiol. 2000, 35, 125-142. [CrossRef]

180. Rupawala, M.; Dehghani, H.; Lucas, S.J.; Tino, P.; Cruse, D. Shining a Light on Awareness: A Review of Functional Near-Infrared Spectroscopy for Prolonged Disorders of Consciousness. Front. Neurol. 2018, 9, 68. [CrossRef]

181. Delpy, D.T.; Cope, M. Quantification in tissue near-infrared spectroscopy. Philos. Trans. R. Soc. B Boil. Sci. 1997, 352, 649-659. [CrossRef]

182. Hamaoka, T.; McCully, K.K. Review of early development of near-infrared spectroscopy and recent advancement of studies on muscle oxygenation and oxidative metabolism. J. Physiol. Sci. 2019, 69, 799-811. [CrossRef]

183. Bakker, A.; Smith, B.; Ainslie, P.N.; Smith, K. Near-Infrared Spectroscopy. In Introduction//New Directions in the Dynamic Assessment of Brain Blood Flow Regulation; Willie, C.K., Eller, L.K., Ainslie, P.N., Eds.; INTECH Open Access Publisher: London, UK, 2012; pp. 65-88. ISBN 978-953-51-0522-0.

184. Scholkmann, F.; Metz, A.J.; Wolf, M. Measuring tissue hemodynamics and oxygenation by continuous-wave functional near-infrared spectroscopy-How robust are the different calculation methods against movement artifacts? Physiol. Meas. 2014, 35, 717-734. [CrossRef]

185. Kohl-Bareis, M. NIRS: Theoretical Background and Practical Aspects. In Functional Neuroimaging in Exercise and Sport Sciences; Boecker, H., Hillman, C.H., Scheef, L., Strüder, H.K., Eds.; Springer: New York, NY, USA, 2012; pp. 213-235. ISBN 978-1-4614-3292-0.

186. Almajidy, R.J.; Mankodiya, K.; Abtahi, M.; Hofmann, U.G. A Newcomer's Guide to Functional Near Infrared Spectroscopy Experiments. IEEE Rev. Biomed. Eng. 2020, 13, 292-308. [CrossRef]

187. Quaresima, V.; Bisconti, S.; Ferrari, M. A brief review on the use of functional near-infrared spectroscopy (fNIRS) for language imaging studies in human newborns and adults. Brain Lang. 2012, 121, 79-89. [CrossRef] [PubMed]

188. Ferrari, M.; Quaresima, V. A brief review on the history of human functional near-infrared spectroscopy (fNIRS) development and fields of application. NeuroImage 2012, 63, 921-935. [CrossRef]

189. Irani, F.; Platek, S.M.; Bunce, S.; Ruocco, A.C.; Chute, D. Functional Near Infrared Spectroscopy (fNIRS): An Emerging Neuroimaging Technology with Important Applications for the Study of Brain Disorders. Clin. Neuropsychol. 2007, 21, 9-37. [CrossRef] [PubMed]

190. Hoshi, Y. Functional Near-Infrared Spectroscopy: Potential and Limitations in Neuroimaging Studies. Int. Rev. Neurobiol. 2005, 66, 237-266. [CrossRef]

191. Hoshi, Y.; Yamada, Y. Overview of diffuse optical tomography and its clinical applications. J. Biomed. Opt. 2016, 21, 91312. [CrossRef]

192. Elwell, C.; Cooper, C. Making light work: Illuminating the future of biomedical optics. Philos. Trans. A Math. Phys. Eng. Sci. 2011, 369, 4358-4379. [CrossRef] [PubMed]

193. Agbangla, N.F.; Audiffren, M.; Albinet, C. Use of near-infrared spectroscopy in the investigation of brain activation during cognitive aging: A systematic review of an emerging area of research. Ageing Res. Rev. 2017, 38, 52-66. [CrossRef] 
194. Shoaib, Z.; Kamran, M.A.; Mannan, M.M.N.; Jeong, M.Y. Methodologies on the Enhanced Spatial Resolution of Non-Invasive Optical Brain Imaging: A Review. IEEE Access 2019, 7, 130044-130066. [CrossRef]

195. Kumar, V.; Shivakumar, V.; Chhabra, H.; Bose, A.; Venkatasubramanian, G.; Gangadhar, B.N. Functional near infra-red spectroscopy (fNIRS) in schizophrenia: A review. Asian J. Psychiatry 2017, 27, 18-31. [CrossRef] [PubMed]

196. Strangman, G.; A Boas, D.; Sutton, J.P. Non-invasive neuroimaging using near-infrared light. Boil. Psychiatry 2002, 52, 679-693. [CrossRef]

197. Rooks, C.R.; Thom, N.J.; McCully, K.K.; Dishman, R. Effects of incremental exercise on cerebral oxygenation measured by near-infrared spectroscopy: A systematic review. Prog. Neurobiol. 2010, 92, 134-150. [CrossRef]

198. Boone, J.; Vandekerckhove, K.; Coomans, I.; Prieur, F.; Bourgois, J.G. An integrated view on the oxygenation responses to incremental exercise at the brain, the locomotor and respiratory muscles. Eur. J. Appl. Physiol. 2016, 116, 2085-2102. [CrossRef]

199. Noakes, T.D. Testing for maximum oxygen consumption has produced a brainless model of human exercise performance. Br. J. Sports Med. 2008, 42, 551-555. [CrossRef]

200. Noakes, T.D.; E Peltonen, J.; Rusko, H.K. Evidence that a central governor regulates exercise performance during acute hypoxia and hyperoxia. J. Exp. Boil. 2001, 204, 3225-3234.

201. Noakes, T.D.; St, C.; Lambert, E.V. From catastrophe to complexity: A novel model of integrative central neural regulation of effort and fatigue during exercise in humans. Br. J. Sports Med. 2004, 38, 511-514. [CrossRef]

202. Noakes, T.D.; St, C.; Lambert, E.V. From catastrophe to complexity: A novel model of integrative central neural regulation of effort and fatigue during exercise in humans: Summary and conclusions. Br. J. Sports Med. 2005, 39, 120-124. [CrossRef]

203. Noakes, T.D.; Noakes, P.T.D. The Central Governor Model of Exercise Regulation Applied to the Marathon. Sports Med. 2007, 37, 374-377. [CrossRef] [PubMed]

204. Noakes, T.D. Time to move beyond a brainless exercise physiology: The evidence for complex regulation of human exercise performance. Appl. Physiol. Nutr. Metab. 2011, 36, 23-35. [CrossRef] [PubMed]

205. Abbiss, C.R.; Laursen, P.B. Models to explain fatigue during prolonged endurance cycling. Sports Med. 2005, 35, 865-898. [CrossRef] [PubMed]

206. Robertson, C.; Marino, F.E. A role for the prefrontal cortex in exercise tolerance and termination. J. Appl. Physiol. 2016, 120, 464-466. [CrossRef] [PubMed]

207. Yamazaki, Y.; Sato, D.; Yamashiro, K.; Tsubaki, A.; Yamaguchi, Y.; Takehara, N.; Maruyama, A. Inter-individual Differences in Exercise-Induced Spatial Working Memory Improvement: A Near-Infrared Spectroscopy Study. Adv. Exp. Med. Biol. 2017, 977, 81-88. [CrossRef] [PubMed]

208. Mekari, S.; Fraser, S.; Bosquet, L.; Bonnéry, C.; Labelle, V.; Pouliot, P.; Lesage, F.; Bherer, L. The relationship between exercise intensity, cerebral oxygenation and cognitive performance in young adults. Eur. J. Appl. Physiol. 2015, 115, 2189-2197. [CrossRef]

209. Fishburn, F.; Norr, M.E.; Medvedev, A.V.; Vaidya, C.J. Sensitivity of fNIRS to cognitive state and load. Front. Hum. Neurosci. 2014, 8, 76. [CrossRef]

210. Herff, C.; Heger, D.; Fortmann, O.; Hennrich, J.; Putze, F.; Schultz, T. Mental workload during n-back task-quantified in the prefrontal cortex using fNIRS. Front. Hum. Neurosci. 2014, 7, 935. [CrossRef]

211. Causse, M.; Chua, Z.; Peysakhovich, V.; Del Campo, N.; Matton, N. Mental workload and neural efficiency quantified in the prefrontal cortex using fNIRS. Sci. Rep. 2017, 7, 5222. [CrossRef]

212. Bunce, S.C.; Izzetoglu, K.; Ayaz, H.; Shewokis, P.; Izzetoglu, M.; Pourrezaei, K.; Onaral, B. Implementation of fNIRS for Monitoring Levels of Expertise and Mental Workload. Appl. Evol. Comput. 2011, 6780, $13-22$.

213. Mehta, R.K.; Parasuraman, R. Effects of Mental Fatigue on the Development of Physical Fatigue. Hum. Factors J. Hum. Factors Erg. Soc. 2013, 56, 645-656. [CrossRef]

214. Shortz, A.; Pickens, A.; Zheng, Q.; Mehta, R.K. The effect of cognitive fatigue on prefrontal cortex correlates of neuromuscular fatigue in older women. J. Neuroeng. Rehabil. 2015, 12, 115. [CrossRef] [PubMed]

215. Borragan, G.; Guerrero-Mosquera, C.; Guillaume, C.; Slama, H.; Peigneux, P. Decreased prefrontal connectivity parallels cognitive fatigue-related performance decline after sleep deprivation. An optical imaging study. Boil. Psychol. 2019, 144, 115-124. [CrossRef] [PubMed] 
216. Brugnera, A.; Zarbo, C.; Adorni, R.; Gatti, A.; Compare, A.; Sakatani, K. Age-Related Changes in Physiological Reactivity to a Stress Task: A Near-Infrared Spectroscopy Study. Adv. Exp. Med. Biol. 2017, 977, 155-161. [CrossRef] [PubMed]

217. Mandrick, K.; Peysakhovich, V.; Rémy, F.; Lepron, E.; Causse, M. Neural and psychophysiological correlates of human performance under stress and high mental workload. Boil. Psychol. 2016, 121, 62-73. [CrossRef] [PubMed]

218. Mehta, R.K. Stunted PFC activity during neuromuscular control under stress with obesity. Eur. J. Appl. Physiol. 2015, 116, 319-326. [CrossRef] [PubMed]

219. Rosenbaum, D.; Hilsendegen, P.; Thomas, M.; Haeussinger, F.B.; Metzger, F.G.; Nuerk, H.-C.; Fallgatter, A.J.; Nieratschker, V.; Ehlis, A.-C. Cortical hemodynamic changes during the Trier Social Stress Test: An fNIRS study. NeuroImage 2017, 171, 107-115. [CrossRef]

220. Kalia, V.; Vishwanath, K.; Knauft, K.; Von Der Vellen, B.; Luebbe, A.; Williams, A. Acute Stress Attenuates Cognitive Flexibility in Males Only: An fNIRS Examination. Front. Psychol. 2018, 9, 9. [CrossRef]

221. Caen, K.; Vermeire, K.; Pogliaghi, S.; Moerman, A.; Niemeijer, V.; Bourgois, J.G.; Boone, J. Aerobic Interval Training Impacts Muscle and Brain Oxygenation Responses to Incremental Exercise. Front. Physiol. 2019, 10, 1195. [CrossRef]

222. Ono, Y.; Nomoto, Y.; Tanaka, S.; Sato, K.; Shimada, S.; Tachibana, A.; Bronner, S.; Noah, J.A. Frontotemporal oxyhemoglobin dynamics predict performance accuracy of dance simulation gameplay: Temporal characteristics of top-down and bottom-up cortical activities. NeuroImage 2014, 85, 461-470. [CrossRef]

223. Funahashi, S.; Andreau, J.M. Prefrontal cortex and neural mechanisms of executive function. J. Physiol. 2013, 107, 471-482. [CrossRef]

224. Miller, E.K.; Cohen, J.D. An Integrative Theory of Prefrontal Cortex Function. Annu. Rev. Neurosci. 2001, 24, 167-202. [CrossRef] [PubMed]

225. Pontifex, M.B.; McGowan, A.L.; Chandler, M.C.; Gwizdala, K.L.; Parks, A.; Fenn, K.; Kamijo, K. A primer on investigating the after effects of acute bouts of physical activity on cognition. Psychol. Sport Exerc. 2019, 40, 1-22. [CrossRef]

226. Kujach, S.; Byun, K.; Hyodo, K.; Suwabe, K.; Fukuie, T.; Laskowski, R.; Dan, I.; Soya, H. A transferable high-intensity intermittent exercise improves executive performance in association with dorsolateral prefrontal activation in young adults. NeuroImage 2018, 169, 117-125. [CrossRef] [PubMed]

227. Byun, K.; Hyodo, K.; Suwabe, K.; Ochi, G.; Sakairi, Y.; Kato, M.; Dan, I.; Soya, H. Positive effect of acute mild exercise on executive function via arousal-related prefrontal activations: An fNIRS study. NeuroImage 2014, 98, 336-345. [CrossRef]

228. Yanagisawa, H.; Dan, I.; Tsuzuki, D.; Kato, M.; Okamoto, M.; Kyutoku, Y.; Soya, H. Acute moderate exercise elicits increased dorsolateral prefrontal activation and improves cognitive performance with Stroop test. NeuroImage 2010, 50, 1702-1710. [CrossRef]

229. Hyodo, K.; Dan, I.; Suwabe, K.; Kyutoku, Y.; Yamada, Y.; Akahori, M.; Byun, K.; Kato, M.; Soya, H. Acute moderate exercise enhances compensatory brain activation in older adults. Neurobiol. Aging 2012, 33, 2621-2632. [CrossRef]

230. Morais, G.A.Z.; Scholkmann, F.; Balardin, J.B.; Furucho, R.A.; De Paula, R.C.V.; Biazoli, C.E.; Sato, J.R. Non-neuronal evoked and spontaneous hemodynamic changes in the anterior temporal region of the human head may lead to misinterpretations of functional near-infrared spectroscopy signals. Neurophotonics 2017, 5, 1. [CrossRef]

231. Matsukawa, K.; Endo, K.; Asahara, R.; Yoshikawa, M.; Kusunoki, S.; Ishida, T. Prefrontal oxygenation correlates to the responses in facial skin blood flows during exposure to pleasantly charged movie. Physiol. Rep. 2017, 5, e13488. [CrossRef]

232. Miyazawa, T.; Horiuchi, M.; Komine, H.; Sugawara, J.; Fadel, P.J.; Ogoh, S. Skin blood flow influences cerebral oxygenation measured by near-infrared spectroscopy during dynamic exercise. Eur. J. Appl. Physiol. 2013, 113, 2841-2848. [CrossRef]

233. Nasseri, N.; Caicedo, A.; Scholkmann, F.; Zohdi, H.; Wolf, U. Impact of Changes in Systemic Physiology on fNIRS/NIRS Signals: Analysis Based on Oblique Subspace Projections Decomposition. Adv. Exp. Med. Biol. 2018, 1072, 119-125. [CrossRef] 
234. Takahashi, T.; Takikawa, Y.; Kawagoe, R.; Shibuya, S.; Iwano, T.; Kitazawa, S. Influence of skin blood flow on near-infrared spectroscopy signals measured on the forehead during a verbal fluency task. NeuroImage 2011, 57, 991-1002. [CrossRef] [PubMed]

235. Fantini, S.; Ruesch, A.; Kainerstorfer, J.M. Noninvasive Optical Studies of the Brain. Neurophotonics Biomed. Spectrosc. 2019, 25-52. [CrossRef]

236. Fantini, S.; Frederick, B.D.; Sassaroli, A. Perspective: Prospects of non-invasive sensing of the human brain with diffuse optical imaging. APL Photonics 2018, 3, 110901. [CrossRef] [PubMed]

237. Von Lühmann, A.; Li, X.; Müller, K.-R.; Boas, D.A.; Yücel, M.A. Improved physiological noise regression in fNIRS: A multimodal extension of the General Linear Model using temporally embedded Canonical Correlation Analysis. NeuroImage 2020, 208, 116472. [CrossRef] [PubMed]

238. Al-Rawi, P.G.; Smieleweski, P.; Kirkpatrick, P.J. Evaluation of a Near-Infrared Spectrometer (NIRO 300) for the Detection of Intracranial Oxygenation Changes in the Adult Head. Stroke 2001, 32, 2492-2500. [CrossRef]

239. Metz, A.J.; Klein, S.D.; Scholkmann, F.; Wolf, U. Continuous coloured light altered human brain haemodynamics and oxygenation assessed by systemic physiology augmented functional near-infrared spectroscopy. Sci. Rep. 2017, 7, 10027. [CrossRef]

240. Scholkmann, F.; Hafner, T.; Metz, A.J.; Wolf, M.; Wolf, U. Effect of short-term colored-light exposure on cerebral hemodynamics and oxygenation, and systemic physiological activity. Neurophotonics 2017, 4, 1. [CrossRef]

241. Durantin, G.; Gagnon, J.-F.; Tremblay, S.; Dehais, F. Using near infrared spectroscopy and heart rate variability to detect mental overload. Behav. Brain Res. 2014, 259, 16-23. [CrossRef]

242. Borresen, J.; I Lambert, M. Autonomic control of heart rate during and after exercise: Measurements and implications for monitoring training status. Sports Med. 2008, 38, 633-646. [CrossRef]

243. Hottenrott, K.; Hoos, O.; Esperer, H.D. Herzfrequenzvariabilität und Sport. Herz 2006, 31, 544-552. [CrossRef]

244. Plews, D.J.; Laursen, P.B.; Stanley, J.; Kilding, A.E.; Buchheit, M. Training Adaptation and Heart Rate Variability in Elite Endurance Athletes: Opening the Door to Effective Monitoring. Sports Med. 2013, 43, 773-781. [CrossRef] [PubMed]

245. Massaro, S.; Pecchia, L. Heart Rate Variability (HRV) Analysis: A Methodology for Organizational Neuroscience. Organ. Res. Methods 2016, 22, 354-393. [CrossRef]

246. Sen, J.; McGill, D. Fractal analysis of heart rate variability as a predictor of mortality: A systematic review and meta-analysis. Chaos 2018, 28, 072101. [CrossRef] [PubMed]

247. Thayer, J.F.; Åhs, F.; Fredrikson, M.; Sollers, J.J.; Wager, T.D. A meta-analysis of heart rate variability and neuroimaging studies: Implications for heart rate variability as a marker of stress and health. Neurosci. Biobehav. Rev. 2012, 36, 747-756. [CrossRef]

248. Thayer, J.F.; Yamamoto, S.S.; Brosschot, J. The relationship of autonomic imbalance, heart rate variability and cardiovascular disease risk factors. Int. J. Cardiol. 2010, 141, 122-131. [CrossRef]

249. Shaffer, F.; Ginsberg, J. An Overview of Heart Rate Variability Metrics and Norms. Front. Public Health 2017, 5, 258. [CrossRef]

250. Castaldo, R.; Melillo, P.; Bracale, U.; Caserta, M.; Triassi, M.; Pecchia, L. Acute mental stress assessment via short term HRV analysis in healthy adults: A systematic review with meta-analysis. Biomed. Signal Process. Control 2015, 18, 370-377. [CrossRef]

251. Vesterinen, V.; Nummela, A.T.; Heikura, I.; Laine, T.; Hynynen, E.; Botella, J.; Häkkinen, K. Individual Endurance Training Prescription with Heart Rate Variability. Med. Sci. Sports Exerc. 2016, 48, 1347-1354. [CrossRef]

252. Gronwald, T.; Schulze, S.; Ludyga, S.; Hottenrott, K. Evaluierung individueller Trainingsvorgaben auf Basis der Herzfrequenzvariabilität für ein Lauftraining im Freizeit-und Gesundheitssport. Praxis 2016, 105, 1065-1070. [CrossRef]

253. Vesterinen, V.; Häkkinen, K.; Hynynen, E.; Mikkola, J.; Hokka, L.; Nummela, A. Heart rate variability in prediction of individual adaptation to endurance training in recreational endurance runners. Scand. J. Med. Sci. Sports 2011, 23, 171-180. [CrossRef]

254. Hottenrott, K. HRV Regenerationsmanagement: State of Art. Sportärztezeitung 2019, 1, 2-6.

255. Bellenger, C.R.; Fuller, J.T.; Thomson, R.L.; Davison, K.; Robertson, E.Y.; Buckley, J.D. Monitoring Athletic Training Status Through Autonomic Heart Rate Regulation: A Systematic Review and Meta-Analysis. Sports Med. 2016, 46, 1461-1486. [CrossRef] [PubMed] 
256. Gronwald, T.; Hoos, O.; Ludyga, S.; Hottenrott, K. Non-linear dynamics of heart rate variability during incremental cycling exercise. Res. Sports Med. 2018, 27, 88-98. [CrossRef] [PubMed]

257. Gronwald, T.; Hoos, O.; Hottenrott, K. Effects of Acute Normobaric Hypoxia on Non-linear Dynamics of Cardiac Autonomic Activity During Constant Workload Cycling Exercise. Front. Physiol. 2019, 10, 999. [CrossRef]

258. Gronwald, T.; Hoos, O.; Hottenrott, K. Effects of a Short-Term Cycling Interval Session and Active Recovery on Non-Linear Dynamics of Cardiac Autonomic Activity in Endurance Trained Cyclists. J. Clin. Med. 2019, 8, 194. [CrossRef]

259. Gronwald, T.; Hoos, O. Correlation properties of heart rate variability during endurance exercise: A systematic review. Ann. Noninvasive Electrocardiol. 2019, 25, e12697. [CrossRef]

260. Gronwald, T.; Hoos, O.; Hottenrott, K. Influence of Performance Level of Male Runners on Non-linear Dynamics of Heart Rate Variability During a 10Km Race. Int. J. Perform. Anal. Sport 2020, 1-15. [CrossRef]

261. De Godoy, M.F. Nonlinear Analysis of Heart Rate Variability: A Comprehensive Review. J. Cardiol. 2016, 3, 528-533. [CrossRef]

262. Voss, A.; Schulz, S.; Schroeder, R.; Baumert, M.; Caminal, P. Methods derived from nonlinear dynamics for analysing heart rate variability. Philos. Trans. A Math. Phys. Eng. Sci. 2008, 367, 277-296. [CrossRef]

263. Huikuri, H.V.; Mäkikallio, T.H.; Perkiömäki, J. Measurement of heart rate variability by methods based on nonlinear dynamics. J. Electrocardiol. 2003, 36, 95-99. [CrossRef]

264. Colzato, L.S.; Jongkees, B.J.; De Wit, M.; Van Der Molen, M.J.W.; Steenbergen, L. Variable heart rate and a flexible mind: Higher resting-state heart rate variability predicts better task-switching. Cogn. Affect. Behav. Neurosci. 2018, 18, 730-738. [CrossRef] [PubMed]

265. Frewen, J.; Finucane, C.; Savva, G.M.; Boyle, G.; Coen, R.F.; Kenny, R.A. Cognitive function is associated with impaired heart rate variability in ageing adults: The Irish longitudinal study on ageing wave one results. Clin. Auton. Res. 2013, 23, 313-323. [CrossRef] [PubMed]

266. Gillie, B.L.; Vasey, M.W.; Thayer, J.F. Heart Rate Variability Predicts Control Over Memory Retrieval. Psychol. Sci. 2013, 25, 458-465. [CrossRef] [PubMed]

267. Hansen, A.L.; Johnsen, B.H.; Thayer, J.F. Vagal influence on working memory and attention. Int. J. Psychophysiol. 2003, 48, 263-274. [CrossRef]

268. Al Hazzouri, A.Z.; Haan, M.N.; Deng, Y.; Neuhaus, J.; Yaffe, K. Reduced heart rate variability is associated with worse cognitive performance in elderly Mexican Americans. Hypertension 2013, 63, 181-187. [CrossRef] [PubMed]

269. Ranchet, M.; Morgan, J.C.; Akinwuntan, A.E.; Devos, H. Cognitive workload across the spectrum of cognitive impairments: A systematic review of physiological measures. Neurosci. Biobehav. Rev. 2017, 80, 516-537. [CrossRef]

270. Forte, G.; Favieri, F.; Casagrande, M. Heart Rate Variability and Cognitive Function: A Systematic Review. Front. Mol. Neurosci. 2019, 13, 710. [CrossRef]

271. Matos, F.D.O.; Vido, A.; Garcia, W.F.; Lopes, W.A.; Pereira, A. A Neurovisceral Integrative Study on Cognition, Heart Rate Variability, and Fitness in the Elderly. Front. Aging Neurosci. 2020, 12, 51. [CrossRef]

272. Siennicka, A.; Quintana, D.; Fedurek, P.; Wijata, A.; Paleczny, B.; Ponikowska, B.; Danel, D. Resting heart rate variability, attention and attention maintenance in young adults. Int. J. Psychophysiol. 2019, 143, 126-131. [CrossRef]

273. Grässler, B.; Hökelmann, A.; Cabral, R.H. Resting heart rate variability as a possible marker of cognitive decline. Kinesiology 2020, 52, 72-84. [CrossRef]

274. Mather, M.; Thayer, J.F. How heart rate variability affects emotion regulation brain networks. Curr. Opin. Behav. Sci. 2018, 19, 98-104. [CrossRef] [PubMed]

275. Smith, R.; Thayer, J.F.; Khalsa, S.S.; Lane, R.D. The hierarchical basis of neurovisceral integration. Neurosci. Biobehav. Rev. 2017, 75, 274-296. [CrossRef] [PubMed]

276. Thayer, J.F.; Hansen, A.L.; Saus-Rose, E.; Johnsen, B.H. Heart Rate Variability, Prefrontal Neural Function, and Cognitive Performance: The Neurovisceral Integration Perspective on Self-regulation, Adaptation, and Health. Ann. Behav. Med. 2009, 37, 141-153. [CrossRef] [PubMed]

277. Thayer, J.F.; Lane, R.D. Claude Bernard and the heart-brain connection: Further elaboration of a model of neurovisceral integration. Neurosci. Biobehav. Rev. 2009, 33, 81-88. [CrossRef] 
278. Thayer, J.F.; Lane, R.D. A model of neurovisceral integration in emotion regulation and dysregulation. J. Affect. Disord. 2000, 61, 201-216. [CrossRef]

279. Park, G.; Thayer, J.F. From the heart to the mind: Cardiac vagal tone modulates top-down and bottom-up visual perception and attention to emotional stimuli. Front. Psychol. 2014, 5, 278. [CrossRef]

280. Thayer, J. A Neurovisceral Integration Model of Heart Rate Variability. In Reference Module in Neuroscience and Biobehavioral Psychology; Elsevier BV: Amsterdam, The Netherlands, 2017.

281. Javaloyes, A.; Sarabia, J.M.; Lamberts, R.P.; Moya-Ramón, M. Training Prescription Guided by Heart-Rate Variability in Cycling. Int. J. Sports Physiol. Perform. 2019, 14, 23-32. [CrossRef]

282. Kiviniemi, A.; Hautala, A.J.; Kinnunen, H.; Tulppo, M. Endurance training guided individually by daily heart rate variability measurements. Eur. J. Appl. Physiol. 2007, 101, 743-751. [CrossRef]

283. Da Silva, D.F.; Ferraro, Z.M.; Adamo, K.B.; Machado, F.A. Endurance Running Training Individually Guided by HRV in Untrained Women. J. Strength Cond. Res. 2019, 33, 736-746. [CrossRef]

284. Scholkmann, F.; Wolf, U. The Pulse-Respiration Quotient: A Powerful but Untapped Parameter for Modern Studies About Human Physiology and Pathophysiology. Front. Physiol. 2019, 10, 371. [CrossRef]

285. Scholkmann, F.; Zohdi, H.; Wolf, U. The resting-state pulse-respiration quotient of humans: Lognormally distributed and centred around a value of four. Physiol. Res. 2019, 68, 1027-1032. [CrossRef] [PubMed]

(C) 2020 by the authors. Licensee MDPI, Basel, Switzerland. This article is an open access article distributed under the terms and conditions of the Creative Commons Attribution (CC BY) license (http://creativecommons.org/licenses/by/4.0/). 